\title{
A IMPORTÂNCIA DO DIREITO ORDINÁRIO FRENTE À SUPREMACIA DA CONSTITUIÇÃO
}

$\overline{\text { Marcelo Schenk Duque }}$

Introdução; 1. A jurisdição constitucional e o exame da compatibilidade dos meios idealizados pelo legislador para atingir determinado fim; 2. Necessidade de uma política legislativa sobre direitos fundamentais; 3 . Necessidade de se prestigiar o direito ordinário; 4. Importância da função judicial; 5. A primazia do legislador na concretização da Constituição; Considerações finais; Referências bibliográficas.

\section{Introdução}

O presente trabalho tem por objetivo realizar breves reflexões acerca da importância do direito ordinário frente à condição de supremacia da Constituição. O tema é invariavelmente complexo e, certamente, rende trabalhos de fôlego. Não obstante, um olhar atento a algumas considerações doutrinárias relevantes contribui para revelar alguns aspectos fundamentais para a compreensão da importância do direito ordinário em sua relação com a supremacia da Constituição. A questão que se coloca, nesse desiderato, é verificar se a condiçāo de supremacia da Constituição impõe, de uma forma ou de outra, um desprestígio às leis infraconstitucionais, sob a égide de um Estado Democrático de Direito².

Doutorando em Direito do Estado pela Universidade Federal do Rio Grande do Sul, bolsista da CAPES.

O termo "Estado Democrático de Direito" é aqui utilizado em uniformidade conceitual com o art. $11^{\circ}$ da Constituição da República Federativa do Brasil de 1988, muito embora reconheça-se que, sobretudo na tradição constitucional alemã, a expressão seja cunhada, simplesmente, como "Estado de Direito". Vide, por todos, HECK, Luís Afonso. O Tribunal Constitucional Federal e o Desenvolvimento dos Princípios Constitucionais. Contributo para uma compreensão da jurisdição constitucional federal alemã. Porto Alegre: Sergio Antonio Fabris, 1995, p. 175 e ss; sobre o conceito de Estado de Direito remeta-se à leitura de SCHNEIDER, Hans Peter. Democracia y Constitucion. Madrid: Centro de Estudios Constitucionales, 1991, p. 137. Em apertada síntese, Schneider afirma - sob a ótica da Constituição Alemã - que o Estado de Direito pode ser compreendido como um "sistema de principios e regras processuais segundo as quais se cria e se aperfeiçoa o ordenamento juridico, se limita e controla o poder estatal e se protegem e realizam os direitos do indivíduo à liberdade" (em traduçâo livre do autor); ademais, registre-se que na doutrina há quem afirme, inclusive, que o conceito de Estado de Direito deriva do conceito de supremacia da Constituiçāo. Nesse sentido, vide REYES, Manuel Aragón. El Juez Ordinario entre Legalidad y Constitucionalidad. Bogotá: Instituto de Estudios Constitucionales Carlos Restrepo Piedrahita, 1997, p. 16. 


\section{A jurisdição constitucional e o exame da compatibilidade dos meios idealizados pelo legislador para atingir determinado fim}

$\mathrm{Na}$ esteira do que leciona Konrad Hesse ${ }^{3}$, na relação entre a jurisdição constitucional e a legislação ordinária coloca-se a questão de quem é chamado, em primeiro lugar, para concretizar a Constituição? A resposta a essa questão tem o condão de descortinar o modo pelo qual o direito ordinário se coloca em relação com a Constituição. Isso porque a condição de supremacia ${ }^{4}$, a qual encerra uma verdadeira tônica no conceito de Constituiçāo ${ }^{5}$, representa a razão pela qual o legislador ordinário é, em certo sentido, destronado, ao ver a sua atuação submetida a limitações cuja transgressão pode vir a ser sancionada, não politicamente, mas juridicamente, pela invalidação das normas produzidas em face de contrariedade com os preceitos vigentes na Constituição ${ }^{6}$.

No entanto, embora não pairem dúvidas de que a Constituição é a norma suprema do ordenamento jurídico, sobretudo pelo fato de que a hierarquia entre as normas é pressuposto necessário para a consolidação desse caráter supremo ${ }^{7}$, cumpre asseverar, como ponto de partida para as considerações desse estudo, que o reconhecimento da condição de supremacia da Constituição não importa, de maneira alguma, em um desprestígio do direito ordinário ${ }^{8}$.

3 HESSE, Konrad. Elementos de Direito Constitucional da República Federal da Alemanha. Traduzido por Luís Afonso Heck. Potto Alegre: Sergio Antonio Fabris, 1998. Tradução de: Grundzüge des Verfassungsrechts der Bundesrepublik Deutschland" 20., neubearbeitete Auflage, p. 73.

4 Conforme a clássica liçăo de KELSEN, Hans. Wesen und Entwicklung der Staatsgerichtsbarkeit. In: Veröfentlichungen der Vereinigung der Deutschen Staatsrechtslehrer (VDStRL), Heft 5. Berlin und Leipzig: Walter de Grunyter, 1929, p. 32, extrat-se que a supremacia da Constituiçảo importa em dois aspectos distintos, que expressam que cada grau da ordem jurídica representa, ao mesmo tempo, uma produção de Direito perante o grau inferior e uma reprodução do Direito perante o grau superior: o primeiro aspecto, de caráter material, questiona se uma determinada disposiçăo legal viola o conteúdo da Constituição, de modo que nentum poder por ela constituido poderá atuar de forma contrária ao que dispöe a Constituição; o segundo aspecto, de caráter formal, aponta para a fixação das regras de procedimento do processo legislativo, que, de igual maneira, devem estar em conformidade com os ditames da Constituição. A partir desse raciocínio, Kelsen defende a tese de que a conformidade ao Direito (Rechtmäbigkeit) nada mais é cio que a relação de correspondencia de um grau inferior, com um grau superior da orden juridica.

5 Sobre o conceito de Constituiçăo remeta-se à obra de HESSE, Konrad. Elementos de Direito Constitucional da República Federal da Alemanha..., p. 37, quando afirma que "a Constituição é a ordem fundamental juridica da coletividade".

- Cf. LlLORENTE, Francisco Rubio. la Forma del Poder. Estudios sobre la Constitución. 2.ed. Centro de Estudios Constitucionales: Madrid, 1997, p. 574.7 KELSEN, Hans. Reine Rechtslehre. 2. erw. Auflage. Wien: Franz Deuticke, 1983, p. 228, afirmando que ao se levar em conta apenas a ordem juridica estatal, a Constituição representa o escalão de direito positivo mais elevado. Segundo Kelsen, a Constituiçăo em sentido material representa a norma positiva, ou as nomas positivas por intermédio das quais é regulada a produção das normas jurídicas gerais, em um cenário onde propugna pela necessidade de existência de uma lei superior capaz de limitar o poder estatal.

* Na liçăo coincidente de REYES, Manuel Aragón. El Juez Ordinario entre Legalidad y Constitucionalidad..., p. 25, a dupla vinculaçăo dos juizes à Constituiçảo e à legisłaçảo ordinária apresenta o risco de fazer com que os juizes se desliguem da lei por entenderem-se mais ligados à Constituiçāo e, sem que submetam a questão perante o tribunal constitucional competente, deixem de aplicar a lei para, em seu lugar, aplicar não as regras ou principios constitucionais, mas sim valores constitucionais de conteúdo indeterminado, que, por essa razão, possuem apenas eficácia interpretativa. 
Ciente dessa realidade, deve-se admitir com ressalvas a ampla possibilidade, como é pregado por parte da doutrina pátria9, de a jurisdição constitucional proceder ao exame da compatibilidade dos meios idealizados pelo legislador para atingir determinado fim, dentre as opções políticas verificadas no momento da elaboração de uma lei ${ }^{10}$.

9 Vide, de forma exemplificativa, BARROS, Suzana de Toledo. O Princípio da Proporcionalidade e o Controle de Constitucionalidade das Leis Restritivas de Direitos Fundamentais. 2.ed. Braślia: Braślia Juridica, 2000, p. 24-25, quando defende a idéia de que a violação do conteúdo de certos princípios constitucionais "aponta para a necessidade de o judiciário proceder ao exame da compatibilidade dos meios idealizados pelo legislador para atingir determinado fim, entre as opçöes políticas que the eram possiveis quando da elaboraçăo da lei".

10 Essa limitação do âmbito de atuação da jurisdiçăo constitucional verifica-se, a propósito, na linha que, desde a primeira sentença do Tribunał Constitucional Federał alemão sobre o aborto (BVerfGE 39, 1), de 25/02/1975 (ocasiäo em que se questionava a obrigatoriedade constitucional de o legislador sancionar penalmente a prática do aborto), passou a ser considerada na jurisdição constitucional alemã. Remetamse, nesse sentido, às consideraçóes proferidas (em sede de votos dissidentes), pela juiza Rupp von Brünneck e pelo Juiz Dr. Simon, quando afirmaram que a faculdade (Befugnis) de o tribunal constitucionalanular decisóes do legislador ordinário exige um uso parcimonioso, caso se queira evitar um deslocamento (Verschiebung) dos pesos entre os orgăos constitucionais. Nesse passo, o mandamento de autolimitação judicial (richterlicher Selbstbeschrärkung), descrito na doutrina de Leibholz (referência no original) como o "elixir da vida" (Lebenselexier) da jurisprudencia do Tribunal Constitucional Federal alemäo, vale, sobretudo, quando se deva dar ao legislador, legitimado diretamente pelo povo no curso do controle jurídico-constitucional, prescriçóes para a conformaçăo (Gestaltung) positiva da ordem social. [BVerfGE 39, 1, (69-70)]. Na segunda sentença do Tribunal Constitucional Federal alemāo sobre o aborto (BVerfGE 88,203 ), de $28 / 05 / 1993$ (ocasião em que se discutia a possibilidade de a proteçăo da vida uterina ocorrer, nas primeiras doze semanas de gestaçäo, por meio de sessöes de aconselhamento oficial à gestante - cuja função era convencê-la de dar à luz, mediante esclarecimentos necessários e apolo social-previdenciário capaz de facilitar o prosseguimento da gravidez, provendo as condiçôes para o nascimento - em detrimento da tipificação de sanção penal, quando esse aconseh hamento oficial concluísse pela necessidade excepcional de interrupçăo da gravidez, como, por exemplo, em casos de risco de morte da gestante), assentou-se que é tarefa do legislador determinar, nos pormenores, o modo e a extensăo da proteçăo (no caso, outorgada pelo direito fundamental de proteção à vida). Firmou-se, nessa linha, o entendimento de que a Constituiçâo estabelece a proteçāo como meta, não detalhando, contudo, a sua conformaçăo nos pormenores $B$ BVerfGE 88,203 (254)]. No mais, à decisāo afirmou que o Estado deve, para cumprir o seu dever de proteção da vida intra-uterina, tomar medidas normativas e fáticas suficientes, que conduzam a uma proteçāo adequada e, como tal, eficiente, observando-se bens jurídicos antagónicos. Para tainto, faz-se necessário o desenvolvimento de um plano de proteção (Schutzkonzept) que combine elementos de proteçảo preventiva e repressiva. Interessa, para o presente estudo, que o Tribunal Constitucional Federal alemão firmou o entendimento de que a montagem e a transposição normativa (Aufstellung und normative Umsetzung) desse plano de proteçāo é "coisa" (Sache) do legislador, ou seja, assunto, interesse e tarefa do direito ordinário. [BVerfGE 88,203 (261). Como base nessa constatação, aqueletribunal ponderou que o legistador, em que pese não ser livre para considerar o aborto praticado em todo e qualquer caso como permitido (assim, somente hipóteses legais de exceção irrefutáveis jứdico-constitucionalmente poderiam justificáio), pode estabelecer, de acordo com alguns critérios desenvolvidos pela própria decisäo, de que forma ele efetivará, em princípio, a proibição do aborto nos diferentes âmbitos do ordenamento juridico. A enumeração desses critérios assume relevo, pois leva à compreensäo da relaçăo entre o direito ordinário e a Constituição: observe-se, em um primeiro momento, que o Tribunal Constitucional Federal alemão afimou que o legislador deve submeter a eleição e a configuração do seu plano de proteção a uma avaliação jurídicoconstitucionalmente sustentável (verfassungsrechtlich tragfähige Einschätzung), de modo que com esse plano a proteção à vida intra-uterina seja tăo garantida, quanto o exige a proibição de insuficiencia (Unterna B verbot). À medida que as suas decisóes desenvolvam simultaneamente prognósticos (Prognosen) sobre desenvolvimentos fáticos, particularmente os que estão na base dos efeitos das suas regulamentaçōes, tais prognósticos devem ser confiáveis. O tribunal constitucional examina se esses prognósticos são legítimos (vertretbar), à medida dos seguintes critérios: cabe ao legislador um espaço de conformação, de valoraçăo e de avaliação (também) quando ele é juridico-constitucionalmente obrigado a tomar medidas suficientes e eficazes para a proteção de um bem juridico. 
Ocorre que a livre criação que caracteriza a liberdade conformadora do legislador recua, como advertiu Hans Kelsen" ${ }^{*}$, quase que completamente, em sede de jurisdição constitucional: trata-se da sua famosa formulação do tribunal constitucional como legislador negativo (negative Gesetzgeber). De outra banda, como bem intuiu Georg Jellinek ${ }^{12}$, um mesmo fim pode ser alcançado por diferentes meios, de modo que o simples conhecimento desse fim não indica, por si só, os possíveis meios para realizá-lo. Trata-se, portanto, de tarefa ideologizante que requer, necessariamente, a ação de órgãos políticos de legiferação ${ }^{13}$. Note-se, ademais, que a contemplação dos valores supremos ${ }^{14}$ do Estado Democrático de Direito representa um elemento regulador da

\begin{abstract}
A extensăo desse espaço depende de fatores de diversos tipos, particularmente da modalidade especifica do assunto em questảo (no ambito da coisa), das possibilidades - sobretudo sobre o futuro desenvolvimento e as consequêencias de uma norma - de formar para si um juízo suficientemente seguro e do significado, no jogo, dos bens jurídicos em questăo. Assim, o exame jurídico-constitucional estende-se, em cada caso, se - legislador considerou suficientemente os fatores mencionados e se ele se valeu de seu espaço de avaliaçäo de "maneira legitima" (in vertretbarer Weise) [BVerfGE 88, 203 (262)]. (À guisa de informaçăo, o Tribunal Constitucional Federal alemăo, nessa sentença, julgou inconstitucionais os dispositivos legais que autorizavam o aborto que, apos uma sessāo de aconselhamento, era aconselhado independentemente de existir estado de necessidade da gestante para tanto. Considerou-se, ainda, que os moldes do aconselímamento previsto na legisłação cuja constitucionalidade fora questionada não cumpria, de maneira suficiente, o objetivo fundamental de encorajar a gestante a dar à luz. Assim, o referido tribunal fixou uma série de ordens transitórias, até a entrada em vigor da nova regulamentação legal de confornaçăo do procedimento do aconsehamento - BVerfGE 88, 203 (208-213)). N. A: BVerfGE é a abreviatura, em àlemão, de Entscheidungen des Bundesverfassungsgerichts, que, traduzindo para o português, significa "decisões do Tribunal Constitucional Federal alemåo". O primeiro algarismo indica o número do tomo, o segundo a folha inicial da decisão e os demais, entre parenteses, as folhas referidas. Os argumentos referidos nas sentenças são ora transcritos em traduçăo livre do autor, porem, em forma fragmentada.
\end{abstract}

"KELSEN, Hans. Wesen und Entwicklung der Staatsgerichtsbarkeit..., p. 55-56, explicando que a atividade de legislador negativo decorre do fato de o tribunal constitucional, na condiçăo de orgão jurisdicional independente, possuir a competencia para retirar uma tei inconstitucional do mundo juridico, por meio do efeito cassatório das suas decisóes.

:2 JELLINEK, Georg. Teoria General dej Estado. Traduzido por Fernando de los Rios. Buenos Aires: Albatros, 1971. Traduça de: Allgemeine Staatslehre, p. 177.

13 Cf. SOUZA JUNIOR, Cezar Saldanha. Direito Constitucional, Direito Ordinário, Direito Judiciário. Cadenos do Programa de Pós-Graduação em Direito da Universidade Federal do Rio Grande do Sul, março de $2005, p, 14$.

is Nesse ponto, faz-se necessária uma advertência importante, com base nas observaçöes de HESSE, Konrad. Elementos de Direito Constitucional da Repúbtica Federal da Alemanha..., p. 44, no sentido de que o recurso à determinação dos fins supremos do ordenamento jurídico năo pode, em nenhum momento, servir de meio para ludibriar a Constituição, no instante em que a sua respectiva eleiçäo pode representar um interesse discricional pretensamente superior, cuja hierarquia é, em geral, controvertida. A posição de Hesse reforça, portanto, a necessidade de uma argumentação racionał em torno da escolha e recurso a esses fins, de modo a que a Constituiçăo näo seja abandonada por conta "da insegurança gerada por uma luta permanente de poderes e de opiniōes que, em sua argumentação, nâo logram êxito em referir-se a uma base comum"; em sintonia com esse entendimento, depreende-se, a partir da leitura de ALEXY, Robert. Theorie der juristischen Argumentation. Die Theorie des rationalen Diskurses als Theorie der juristischen Begründung. 3. Auflage. Frankfurt am Main: Suhrkamp Taschenbuch Wissenschaft, 1996, p. 147, que a eleição dos fins supremos do ordenamento jurídico depende, ao fim e ao cabo, da argumentaçăo jứdico-fundamental empregada aos interesses em jogo, no instante em que no centro da lógica do discurso jurídico está o argumento que sustenta as escolhas valorativas que se apresentam no caso concreto. Deve ficar claro, entretanto, como o próprio Autor en outra passagem esclarece $\{p .433$, que se por um lado a racionalidade do discurso jurídico não pode, por certo, determinar o conteúdo da decisazo, ela pode, por outro lado, configurar (bilden) os fundamentos para a incorreção da decisāo e os critérios para a sua crítica. 
atividade política ${ }^{15}$, sendo, por conseguinte, assunto do legislador considerar esse componente no curso de sua atividade legiferante, cabendo-lhe a escolha, dentre as alternativas possiveis, na concretização normativa de um preceito constitucional' ${ }^{16}$.

A essa altura e com base nessas considerações preliminares, já se pode delinear o aspecto fundamental da reflexão ora proposta: ao mesmo tempo em que deva existir uma preocupação latente em se garantir a efetividade dos direitos consagrados na Constituição - sobretudo os fundamentais - há que se despender um esforço, quiçá de mesma intensidade, para que as opçōes políticas do legislador sejam respeitadas. Isso porque o pluralismo ${ }^{17}$ político e ideológico é requisito essencial de um Estado Democrático de Direito, efetivado em um ambiente onde a concreção dos valores supremos ${ }^{19}$ do ordenamento jurídico admite a variedade de ideologias ${ }^{19}$. E, nessa conexão de elementos, não há como se afastar do fato de que em todos os casos mais ou menos problemáticos são necessárias valorações que não podem ser tomadas independentemente (nicht zwingend) do material dado e dotado de autoridade $^{20}$, isto é, da lei vigente.

Em face dessa realidade, a jurisdição constitucional não pode pretender tomar o lugar do legislador democraticamente eleito, atitude que implicaria a realização do papel típico da atividade legislativa. Tal entendimento acaba, de certo modo, por aproximar-se da concepção de que a incorporação de preceitos

35 Cf. JELLINEK, Georg. Teoria General del Estado,.., p. 177.

16 Cf. HECK, Luís Afonso. O Tribunal Constitucional Federal e o Desenvolvimento dos Princípios Constitucionais. Contributo para uma compreensão da jurisdição constitucional federal alemã..., p. 175, destacando que na concretizaçäo devem estar mantidos elementos fundamentais do Estado de Direito.

17 Cf. KELSEN, Hans. Wer soll der Hüter der Verfassung sein? In: Die Justiz. Monatsschrift für Erneuerung des Deutschen Rechtswesens, Band V1, 0 Doppelheft 11/12. Berlin-Grunewatd, 1930-1931, p. 602 e 604, o pluralismo consiste em uma esfera de vida social livre do Estado (Staatsfreie Sphäre geselischaftlichen Lebens), de onde surjam, de diferentes lados, influencias sobre a formação da vontade estatal (Staatliche Willensbildung), sobretudo por uma ampla articulaçăo do povo em partidos políticos.

3. Essa concreção, todavia, há que observar certos limites. Nesse particular, conforme noticia HESSE, Konrad. Elementos de Direito Constitucional da República Federal da Alemanha..., p. 66 (nota 31), é inadmissível dar primazia a "bens comunitários superiores" nảo protegidos constitucionalmente, que se deixam sustentar discricionariamente. Ou seja, não se pode interpretar unitateralmente a Constituição, de modo que os seus princlpios devem ser enfrentados e ponderados no plano constitucional, influenciando, sim, o direito ordinârio; porém, sem abafâ-lo. Registre-se, da mesma forma, o entendinento de ALEXY, Robert. Theorie der juristischen Argumentation. Die Theorie des rationalen Diskurses als Theorie der juristischen Begründung..., p. 24, quando áfima que a questăo fundamental é saber onde e em que medida são necessárias valoraçöes (Wertungen), como deve ser determinada a relação dessas valorações com os métodos de interpretação juridica e com os enunciados e conceitos da dogmática jurídica e, sobretudo, como podem ser racionalmente fundamentadas ou justificadas essas valoraçōes.

is Cf. SOUZA JUNIOR, Cezar Saldanhá. Direito Constitucional, Direito Ordinário, Direito Judiciário..., p. 13-14.

20 Cf. ALEXY, Robert. Theorie der Grundrechte. Baden-Baden: Suhrkamp Taschenbuch Wissenschaft, 1994 , p. 498-499, ponderando que a racionalidade do discurso jurídico depende, essencialmente, de se, e em que medida, essas valoraçōes têm aptidăo para um controle racional (no sentido de serem, ou não, racionalmente controláveis). 
substantivos na Constituição deve ser compatível com o pluralismo político, tendo em vista que o legislador não é um mero executor da Constituição, mas sim a expressão de um poder que atua livremente nos limites da moldura constitucional21, sendo que a determinação desses limites é tarefa da interpretação constitucional22. Atente-se, todavia, para um ponto importante: a interpretação torna-se, mais do que nunca, necessária, a partir do momento em que o sentido de um texto não se deixa compreender diretamente, ou seja, sempre que não se quer confiar no que um fenômeno ou apariçāo (Erscheinung) representa diretamente ${ }^{23}$. Além disso, a interpretação da Constituição está vinculada pelo seu texto, ou pela realidade, vale dizer, a algo estabelecido, o que faz com que os limites da interpretação constitucional situem-se exatamente onde não exista um estabelecimento obrigatório da Constituição: dito de outro modo, onde terminam as possibilidades de uma compreensão conveniente, racional e razoável do texto da norma constitucional ${ }^{24}$. Nāo se pode omitir, nessa linha de entendimento, que toda a interpretação constitucional não possui uma resposta unívoca, de modo que não parece possível levar a cabo a sua interpretação em tese $\mathrm{e}^{25}$.

É justamente nesse sentido que assume particular relevância a constatação de que o tribunal encarregado de zelar pela Constituição, com o poder de proferir a última palavra, não deve dizer como o legislador deve, por si mesmo, legislar, sob pena de ferir a autonomia constitucional do Poder Legislativo. A uma, porque não é a sua função ${ }^{26}$; a duas, pelo fato de que a forma de concretização dos direitos fundamentais por meio da atividade legiferante

2 C. LLORENTE, Francisco Rubio. La Forma del Poder. Estudios sobre la Constitución..., p. 577, destacando que, nảo raro, o enunciado dos preceitos esculpidos na Constituiçảo permite um amplo feixe de interpretaçóes diversas, interpretaçöes essas que nảo sảo jurídicas, mas sim políticas, tendo em vista que as nomas constifucionais podem ser entendidas de diversas maneiras, devido ao seu alto grau de abstração. Assim, para Llorente, todo conflito constitucional traduz o enfrentamento entre duas interpretaçóes: a do legislador, marcada pela autoridade da representaçảo popular e a do juiz, pautada pelo Direito.

22 Cf. HESSE, Konrad. Elementos de Direito Constitucional da República Federal da Alemanha..., p. 54, a interpretaçăo ten uma importância decisiva para o direito constituciona, porque em vista da abertura e da amplitude da Constituiçăo, problemas de interpretação nascem mais frequ̇entemente do que em âmbitos jurídicos cujas normalizaçoes entram mais no detaline.

${ }_{23}$ Cf. GADAMER, Hans-Georg. Warheif und Methode. Grundzüge einer philosophischen Hermeneutik. 6. durchgesehende Auflage. Tübingen: J. C. B. Molat (Paul Siebeck), 1990, Band 1, p. 342, destacando que, nessas conexões de sentido, o conceito de interpretaçăo alcança a sua plenitude.

${ }^{24}$ Cf. HESSE, Konrad. Elementos de Direito Constitucional da República Federal da Alemanha..., p. 69, acrescentando a esse quadro (dos timites da interpretação), a circunstância de uma resoluçăo entrar em contradicão unívoca com o texto da norma constitucional.

25 Nesse sentido, vide HESSE, Kontad. Elementos de Direito Constifucional da República Federal da Alemanha..., p. 57, deixando claro que só há falar de interpretação, em face de um caso concreto que se apresente ao intérprete.

26 A clássica lição de HORTA, Raul Machado. Poder legislativo e monopólio da lei no mundo contemporâneo. Revista de Informação Legislativa. Brasília: Senado Federá, ano 31, n. 123, jul.-set. 1994, p. 158, jáafirmava que "no mundo contemporâneo o monopoblio da lei reside no Poder Legislativo. A lei é o ato do Poder Legislativo, nas suas várias determinações $(\ldots)^{\prime \prime}$. 
ordinária é um aspecto que, como já salientado, reclama um ambiente de pluralismo ideológico, ambiente esse que é estranho à jurisdição ${ }^{27}$. Assume relevada importância, nesse marco, o fato de que uma decisão jurídica não pode fundamentar-se estritamente em uma conexão de valorações (Wertungszusammenhang) do ordenamento jurídico ${ }^{28}$; deve, pelo contrário, verificar como os valores penetram na decisão e, principalmente, como podem ser fundamentados, no instante em que as diferentes normas que compõem o mundo jurídico são cristalizações de pontos de vista valorativos completamente diferentes e, não raro, quiçá divergentes ${ }^{29}$. A politização excessiva da jurisdição constitucional é, pois, o maior perigo a que está sujeita ${ }^{30}$.

Note-se que com isso não se afirma que a jurisdiçāo constitucional deva ser totalmente alheia à política, até mesmo pelo fato de que, como paradigmaticamente consignou Francisco Rubio Llorente ${ }^{31}$, para reduzir as tensōes que surgem da relação entre as jurisdições constitucional e ordinária não cabe prescindir totalmente da constitucionalização da política, até mesmo porque quando se pretende arremessá-la pela porta, ela entra pela janela. $O$ que se deseja, em última análise, é que se compreenda que é na Constituição

27. Jurisdiçăo, aqui, é empregada no sentido amplo preconizado por MAURER, Hartmut. Direito Administrativo Geral. Tradução de Lús Afonso Heck. Barueri: Manole, 2006. Tradução de: Allgemeines Verwaltungsrecht - 14 Auflage, p. 168-169: "jurisdição é aplicação do direito; ela compreende a averiguação do fato, a interpretação e, em cáso necessário, o complemento da regulação legal e a subsunção no caso concreto". E prossegue o autor: "a jurisdição tem a função de decidir năo só casos particulares, mas também - com base na decisão do caso particular -.. de concretizar e de continuar a desenvolver o direito".

28 Cf. AlEXY, Robert. Theorie der juristischen Argumentation. Die Theorie des rationalen Diskurses als Theorie der juristischen Begründung..., p. 28-29.

29 Cf. ALEXY, Robert. Theorie der juristischen Argumentation. Die Theorie des rationalen Diskurses als Theorie der juristischen Begründung..., p. 29, demonstrando, com isso, que nenhum princípio jurídico -..e aqui se destacam os principios constitucionais - pode ser realizado ilimitadamente pelo fato de que os princípios carecem de um valor absoluto.

30 Essa é a constataçăo de LLORENTE, Francisco Rubio. La Forma dej Poder, Estudios sobre la Constitución..., p. 182; năo se nega, por outro lado, como oportunamente adverte KELSEN, Hans. Wer soll der Hüter der Verfassung sein?..., p. 587, que a função de um tribunal constitucional acarreta, por si só, um caráter politico em medida muito maior do que a função dos outros tribunais, sem que isso, contudo, faça com que o tribunal constitucional deixe de ser um tribunal, pois a sua função permanece, mesmo assim, sendo jurisdicional (no sentido de fazer justiça - "Justiz").

3) LLORENTE, Francisco Rubio. Divide ef Obtempera? Una reflexión desde España sobre el modelo europeo de convergencia de jurisdicciones en la protección de los derechos. Revista Española de Derecho Constitucional. Madrid: Centro de Estudios Politicos y Constitucionales, n. 67, ano 23, jan.-abr. de 2003, p. 65. Afirma o autor, ainda, que a "constitucionalização da política" é uma conseqúência necessária do controle jurisdicional de constitucionalidade das leis, pelo fato de que a partir do momento em que a conformidade material com a Constituição converte-se em uma condição de validez da lei, enquanto forma necessária para a grande maioria das decisões políticas, a argumentação sobre a sua (in)adequação constitucional converte-se en um elemento central do debate político, que, conseqüentemente, constitucionaliza-se (p. 57). Vide, ainda, do mesmo autor, LLORENTE, Francisco Rubio. La Forma del Poder. Estudios sobre la Constitución..., p. 546, quando afirma que a política e o jurídico mesclam-se em sede de jurisdição constitucional, destacando-se, em vista disso, uma clara tensão entre as jurisdiçoes constitucional e ordinária. 
que o poder político encontra a sua expressão jurídica ${ }^{32}$, o que, entretanto, não afasta a realidade de que a unidade política da Constituição somente desempenha um papel quando é, efetivamente, posta à prova ${ }^{33}$. Não é por menos que Gustavo Zagrebelsky ${ }^{34}$ aponta que a época moderna reclama uma solução de equilíbrio, marcada pela a coexistência de duas vertentes de Direito igualmente essenciais: "uma vertente subjetiva, isenta das incursões da política e uma vertente objetiva, em que as decisões políticas têm que desempenhar legitimamente o seu papel".

\section{Necessidade de uma política legislativa sobre direitos fundamentais}

Resulta assentado que por razões baseadas na garantia do pluralismo, não se deve excluir uma política legislativa sobre os direitos fundamentais, já que esses, embora assegurados pela Constituição, o são somente em face do seu conteúdo essencial e não no completo e detalhado regime do exercício de cada direito, que deve tocar à legislação infraconstitucional ${ }^{35}$. Tal entendimento, em verdade, harmoniza-se com a concepção de que o legislador ordinário deve atuar em função da conformação dos direitos fundamentais no âmbito de discricionariedade ${ }^{36}$ que the permite a delimitação constitucional. Cumpre assentar, nessa perspectiva, que a discricionariedade é uma questão da execução da lei, de modo que justamente no marco da discricionariedade, ou melhor, na apreciação do legislador, é que a legislação converte-se em execução da Constituição ${ }^{37}$. Há, portanto, uma diferença significativa entre pensar que o legislador está vinculado à Constituição, ou pensar que ele tenha que executála diretamente: o legislador, ao desenvolver a lei (no sentido de concretizá-la, dentro do seu âmbito de discricionariedade), executa a lei no marco daquilo que a Constituição preconiza, efetivamente, por estar vinculado à Constituição ${ }^{38}$. A execução da Constituição pelo legislador ordinário, não se dá, pois, de forma direta.

32 Ci. KELSEN, Hans, Wesen und Entwicklung der Staatsgerichtsbarkeit..., p. 36.

3.3 Cf. HECK, Luís Afonso. O Controle Normativo no Direito Constitucional Brasileiro. Revista dos Tribunais. Sta Paulo: Revista dos Tribunais, n, 800, ano 91, jun. 2002, p. 62.

34 ZAGREBELSKY, Gustavo. El Derecho Dúctil. Ley, Derechos, Justicia. Traduzido por Marina Gascón. 3.ed. Madrid: Editorial Trotta, 1999. Traduçào de: ll Diritto Mitte. Legge, Diritti, Giustizia, p. 60.

35 Cf. REYES, Manuel Aragón. El Juez Ordinario entre Legalidad y Constitucionalidad..., p. 33. ${ }^{36}$ Acerca do conceito de discricionariedade, recorre-se ao Direito Adninistrativo, sobretudo em face das liçôes de MAURER, Hartmut. Direito Administrativo Geral..., p. 152, quando afirma que o "poder discricionário significa que a administração tem a escolhà entre modos de conduta diferentes", de formá que tal conceito está atrelado, portanto, às conseqüências juridicas da atuaçăo daquele que elege a respectiva conduta.

37 C. FORSTHOFF, Emst. El Estado de la Sociedad Industrial. Traducido por Luis Lopez Guerra e Jaime Nicolás Muñiz, Madrid: Instituto de Estudios Politicos, 1975. Traduçăo de: Der Staat der Industriegesellschaft, p. 241.

38 Cf. FORSTHOFF, Ennst. El Estado de la Sociedad Industrial..., p. 241-242. 
Anote-se, com ênfase, que não se objeta que o tribunal constitucional deva, ocasionalmente, ocupar-se dos limites da discricionariedade do legislador, em uma extensão ${ }^{39}$ que deve variar de acordo com as peculiaridades da matéria em questão ${ }^{40}$, de modo que se a atividade legiferante vulnerar a respectiva essência dos direitos fundamentais, sua atuação normativa incorrerá em inconstitucionalidade ${ }^{4}$. Isso se sustenta pelo fato de que os direitos fundamentais representam verdadeiras barreiras objetivas ao exercício do poder discricionário ${ }^{42}$ do legislador, ou seja, a vinculação aos direitos fundamentais significa para o legislador uma limitação material de sua liberdade conformadora $^{43}$. Entendimento contrário - não aqui preconizado - implicaria negar o fato de que os direitos fundamentais foram constitucionalizados, justamente, para que o seu conteúdo essencial reste indisponível à ação erosiva do legislador ${ }^{44}$.

Essa perspectiva ressalta, acima de tudo, a importância de se adotar e praticar um sistema lógico-racional para o controle de constitucionalidade das leis. Nessa conexão, só há sentido afirmar que a razão de ser de um controle de constitucionalidade é garantir a supremacia da Constituição frente à lei ${ }^{45}$, quando for possível retirar do mundo jurídico os atos que a violam, pois, do contrário, não há falar, sob pena de inutilidade, em garantia da Constituição ${ }^{46}$ e, menos ainda, em supremacia do Direito ${ }^{47}$. Como corolário desse entendimento, tem-se que a grande missão do controle de constitucionalidade

39 Conforme noticia HESSE, Konrad. Elementos de Direito Constitucional da República Federal da Alemanha..., p. 424, o tribunal constitucional não deve pồ as suas valoraçōes no lugar das vałorações do legislador, sobretudo pelo fato de que a amplitude e a indeterminação dos critérios de controle deixa, muitas vezes, espaços para valorizaçóes diferentes.

so Cf. FORSTHOFF, Ennst. El Estado de la Sociedad Industrial..., p. 243.

4 Cf. MARTINEZZ-PUIALTE, Antonio Luis.la Garantia del Contenido Esencial de los Derechos FundamentalesMadrid: Centro de Estudios Constitucionales, 1997, p. 82.

42. Cf. MAURER, Hartmut. Direito Administrativo Geral..., p. 151.

43 Cf. SARLET, Ingo Wolfgang. A Eficácia dos Direitos Fundamentais. 2.ed. rev. e aum. Porto Alegre: Livraria do Advogado, 2001, p. 328.

45 Cf. LLORENTE, Francisco Rubio. La Forma del Poder. Estudios sobre la Constitución..., p. 339, stblinhando o relevante papel dos juizes na proteção do conteúdo essencial dos direitos fundamentais frente à açăo do legislador.

45 Cf. COMMELA, Victor Ferreres, Las Consecuencias de Centralizar ef Control de Constitucionalidad de la Ley en un Tribunal Especial. Algunas Reflexiones acerca del Activismo Judicial. Disponivel em: <http/ll islandia.law yale.edu/sela/eprogo4.htm> Acesso em: 29 set. 2005, p. 8, destacando o seu ponto de vista sob o enfoque do estabelecimento, no ordenamento jurídico, de uma jurisdição constitucional exercida por um tribunal constitucional.

46 Essa é a dássica lição de KELSEN, Hans. Wesen und Entwicklung der Staatsgerichtsbarkeit..., p. 50 e 52, quando defende a possibilidade de nulificaçäo (Vernichtung) dos atos juridicos que violam a Constituição por parte de um órgão completamente diferente e independente daquele que produziu o ato irregular, a saber, um tribunal constitucional.

47 Sobre a questăo da supremacia do Direito remeta-se à obra de SOUZA JUNIOR, Cezar Saldanha. A Supremacia do Direito no Estado Democrático e seus Modelos Básicos. Porto Alegre: [s.ed.], 2002. 
é verificar se a observância dos direitos fundamentais entrou na pauta do legislador ordinário ${ }^{48}$, à medida que esses direitos mostram-se como verdadeiras barreiras à legislação ${ }^{49}$. Assim, a jurisdição constitucional não se exaure apenas na proteção da Constituição, eis que, ao mesmo tempo, contribui, essencialmente, para o desenvolvimento dos princípios constitucionai $5^{50}$.

Essa constatação possui um significado extremamente relevante para a relação entre o direito constitucional e o direito ordinário, em razão de que a imposição prática da supremacia da Constituição depende que as instâncias ordinárias tenham a competência para examinar a compatibilidade das leis com a Constituição, mas que, paralelamente a isso, o juízo sobre a sua inconstitucionalidade (rejeição) seja reservado, exclusivamente, a um tribunal constitucional ${ }^{51}$, vale dizer, um órgão jurisdicional independente, uma verdadeira instância jurídica (exclusiva) de rejeiçäo da norma inconstitucional ${ }^{52}$. Inexistindo tal configuração, corre-se o risco de perda da unidade material da Constituição ${ }^{53}$, quebrando-se, por conseguinte, a racionalidade da ordem normativa, ao custo de se esvair a certeza e a segurança do ordenamento jurídico.

Afirma-se, nesse tom, que a supremacia da Constituição realmente vale se, ao lado de um eficaz controle de constitucionalidade, existir uma instância jurídica, inserida no âmbito da jurisdição constitucional, que possua competência exclusiva para a rejeição de atos normativos inconstitucionais ${ }^{54}$. Nessa conectividade, pode-

4 A propósito, de acordo com o magistério de PIEROTH, Bodo; SCHLINK, Bernhard. Grundrechte Staatsrecht 11. 16., neubearbeitete Auflage. Heidelberg: C.F. Müller Verlag, 2000, Rdn. 846, p. 207, o aumento da intensidade de violação de um direito fundamental importa na dininuição da liberdade de conformaçâo (Gestaltungsfreineit) do legislador.

19 Cf. STERN, Klaus. Das Staatsrecht der Bundesrepublik Deutschland. München: C.H. Beck'sche Verlagsbuchhandlung, 1988, Band $11 / 1$, p. 1.257, acrescentando que os direitos fundamentais são limites ao exercicio das competências do legislador.

s) Cf. HECK, Luís Aforso. O Tribunal Constitucional Federal e o Desenvolvimento dos Princípios Constitucionais. Contributo para uma compreensão da jurisdiçäo constitucional federal alemă..., p. 167168, sustentando que á atuação do tribunal constitucional no desenvolvimento dos princípios constitucionais baseia-se, entre outros aspectos, na perspectiva de um consenso-limite, no qual devem ser possibilitadas múttiplas discussôes políticas e concretizaçŏes jutrdicas.

51 Cf. HESSE, Konrad. Verfassungsrecht und Privatrecht. Heidelberg: C. F. Muller Juristischer Verlag, 1988, p. 21.

52 Fssa idéia é defendida, com vigor, por KELSEN, Hans. Wesen und Entwicklung der Staatsgerichtsbarkeit..., p. 48 .

53 De acordo com a lição de HESSE, Konrad. Elementos de Direito Constitucional da República Federal da Alemanha..., p. 65, o princípio da unidade da Constituiçăo informa que a "conexăo e a interdependência dos elementos individuais da Constituição fundamentam a necessidade de olhar nunca somente a noma individual, senão sempre tambem a conexão total na qual ela deve ser colocada". Em outra passagem, Hesse assenta que a Constituição somente pode ser completamente compreendida e interpretada se for entendida, efetivamente, no sentido de unidade, à medida que o direito constitucional está dirigido muito más para a ordenaçảo de conjunto, do que para demarcação e exclusão (p. 39).

${ }^{54}$ Esse é um dos pontos que denota o problema da cumulação das jurisdiçóes ordinária e constitucional verificada no modelo brasileiro de controle de constitucionalidade. 
se, então, sustentar que o limite entre o admissivel e o inadmissível e entre o lícito e o llícito é determinado, em sede de jurisdição constitucional, com base na noção de essencialidade ${ }^{55}$. Cabe a referência, portanto, às palavras de Pimenta Bueno ${ }^{56}$, cuja atualidade recomendam sua transcrição:

Ele [o poder judicial] não é autorizado a invadir as raias do poder legislativo, não tem por isso mesmo direito de decretar decisões por via de disposição geral, e só sim de estabelecêlas em relação à espécie que the é subordinada. Não possui jurisdiçāo para decidir questões de ordem administrativa, pois que pertencem à competência exclusiva do governo.

Não menos importante é a observaçāo de José Néri da Silveira ${ }^{57}$ :

[...] o Juiz, enquanto órgão do Poder Judiciário, não está autorizado, pela ordem constitucional, a desprezar a lei válida e decidir o caso concreto, por critérios pessoais, subjetivos, qual estivesse a criar a norma que lhe pareça mais justa ou mais conveniente, a solver a hipótese em exame. A autoridade do Juiz decorre da Constituição e das leis em conformidade com a Carta Magna. A só investidura como autoridade judiciária não the empresta aptidão a decidir, discricionariamente, tão-só, por invocação de princípios ideológicos ou de convicções pessoais, deixando à margem a lei válida (isto é, conforme a Constituiçāo), aplicável à espécie. De contrário, seria admitir a substituição do legislador pelo Juiz, com evidente desconsideração ao preceito básico do sistema democrático relativo à separação e harmonia dos Poderes, cujo exercício há de dar-se nos limites deferidos na Constituição. Com isso, não diminui a independência do magistrado na sua legitimação para, em solvendo litígios, interpretar a lei, atento a seus fins sociais e aos imperativos do bem comum, que também the cumpre promover, no ato de julgar.

Apenas para ilustrar esse ponto, e sem adentrar no mérito da argumentação empregada, cabe trazer à tona a lembrança de Klaus $\mathrm{Stern}^{58}$, no sentido de que

5. Cf. LEORENTE, Francisco Rubio. La Forma del Poder. Estudios sobre la Constifución..., p. 343. Destaca o referido autor, contudo, que a noção de essencialidade é, em si mesma, muito imprecisa, à medida que abre um amplo campo à discricionariedade judicial. O problema, segundo Llorente, é que ainda nảo foi encontrado nenhum conceito melhor, em que pese a realizaçăo de notáveis esforços doutrinários nesse sentido.

56 BUENO, José Antonio Pimenta. Direito Publico Brazileiro e Analyse da Constituição do Imperio. Rio de Janeiro: ) Villeneuve e Cla, 1857, p. 36.

57 SILVEIRA, José Néri da. A Reforma Constitucional e o Controle de sua Constitucionalidade. Revista da Ajuris. Porto Alegre: Associação dos juizes do Rio Grande do Sul, n. 64, juho de 1995, p. 212-213.

58 STERN, Klaus. Das Staatsrecht der Bundesrepublik Deutschland. 2. neubearbeitete Auflage. München: C.H. Beck'sche Verlagsbuchhandlung, 1984, Band 1, p. 23. 
tanto o Direito, quanto a política, não são em si mesmo dimensões últimas (letzte Größen), tendo em vista que ambos estão a serviço de um objetivo superior, qual seja, a promoção da justiça e da dignidade humana. Isso não significa, contudo, que inexistam tensões significativas entre esses dois campos. Essas tensōes sempre existiram e, ao que tudo indica, sempre existirão; podem, entretanto, ser mitigadas, caso se compreenda que o Direito, assim como a Política, são instrumentos para a direção da comunidade e, em sua relação recíproca, vivem, como em um casamento, o compartilhamento (Gemeinsamkeit) e as tensões (Spannungen) ${ }^{59}$. Tal constatação só reforça a idéia de que os níveis do ordenamento jurídico ${ }^{60}$ devem ser respeitados, de acordo com as suas respectivas potencialidades. Ao fim e ao cabo, tudo parece convergir para um velho dilema: o problema da compatibilidade entre o direito constitucional (Verfassungsrecht) e a realidade constitucional (Verfassungswirklichkeit), à medida que, como afirma o jurista alemão Dieter Grimm, as Constituições não podem modificar diretamente a realidade, mas apenas indiretamente influenciá-la ${ }^{61}$.

\section{Necessidade de se prestigiar o direito ordinário}

Diante de tal asserto, parece correta a afirmação de Gustavo Zagrebelsky ${ }^{62}$, no sentido de que a Constituição pode muito, mas não tudo, de modo que se o seu fundamento for apenas o poder, ela assumirá a forma de um castelo de cartas que, a qualquer momento, pode desmoronar. Não é por acaso que Karl Loewenstein ${ }^{63}$ já advertiu que a "Constituição não pode salvar o abismo entre pobreza e riqueza; não pode trazer nem comida, nem casa, nem roupa, nem educação, nem descanso, vale dizer, as necessidades essenciais da vida". Tal assertiva pode ser melhor compreendida parafraseando-se a emblemática lição dos juristas norte-americanos Laurence H. Tribe e Michael C. Dorf ${ }^{64}$, segundo a qual não se deve ler a Constituição como se fosse simplesmente um espelho no qual todos vêem o que desejam ver. Assim,

5. Cf. STERN, Klaus. Das Staatsrecht der Bundesrepublik Deutschland..., Band 1, p. 22-23, destacando que a relaçăo entre o Direito e a Política pertence ao rol dos grandes temas da ciência jurídica, cuja expressão mais recente encerra-se na figura do juiz político, tão exigente, quanto temido.

60 Quanto aos niveis do ordenamento jurídico remeta-se, novamente, a SOUZA JUNIOR, Cezar Saidanha. Direito Constitucional, Direito Ordinário, Direito Judiciário..., p. 15-16.

61 GRIMM, Dieter. Die Zukunft der Verfassung. Frankfupt am Main: Suhrkamp, 1991, p. 17-19.

62 ZAGREBELSKY, Gustavo. La Ley, el Derecho y la Constitución. Revista de Española de Derecho Constitucional. Madrid: Centro de Estudios Políticos y Constitucionales, n. 72, ano 24, set-dez de 2004, p. 22.

6. LOEWENSTEIN, Karl. Teoria de la Constitución. Traduzido por Alfredo Gallego Anabitarte. 2.ed. aum. Barcelona: Ariel, 1976. Traduçăo de: Verfassungstehre, p. 229.

64 TRIBE, Laurence H.; DORF, Michael C. On Reading the Constitution. Cambridge: Harvard University Press, $1991, p .7$. Confira-se a assertiva, no original, em lingua inglesa: is the Constitution simply a mirror in which one sees what one wants to see? 
a concretização do conteúdo de uma norma constitucional e a sua realização somente são possíveis com o emprego das condições da "realidade" que essa norma está determinada a ordenar ${ }^{65}$. A Constituição, portanto, quando lançada pura e simplesmente às mãos dos ideólogos, corre o risco de naufragar em mares que não banham o Estado Democrático de Direito ${ }^{66}$.

É por isso que importa não desprestigiar o direito ordinário em face da supremacia da Constituição. Tratam-se de esferas ${ }^{67}$ autônomas, cada uma com um campo de atuação e potencialidades específicas. Sem a legislação ordinária, a Constituição - e todos os valores que encerra - não pode converter-se em Direito no dia-a-dia das pessoas, dada a abstração dos seus conteúdos. O que se percebe com essa abordagem é que para se garantir o pluralismo, a Constituição deve conter normas abertas, cuja concreção corresponde mais ao legislador, do que ao juiz, o que justifica a existência de um grande número de normas constitucionais estatuídas na forma de princípios $^{68}$ ou de valores ${ }^{69}$.

65 Cf. HESSE, Konrad. Elementos de Direito Constitucional da República Federal da Alemanha..., p. 50 Kaspas no original).

66 Näo é por menos que SOUZA JUNIOR, Cezar Saldantha. Direito Constitucional, Direito Ordinário, Direito Judiciário..., p. 16, afirma que à Constituiçāo "năo é um supermercado donde se possam satisfazer todos os desejos, nem deve ser transformada em uma massa de argila nas mãos dos ideólogos".

67 Aqui o termo esferas é empregado no sentido de âmbito (Bereich), ou seja, para estabelecer uma diferença entre os âmbitos de aplicação do direito constitucional e do direito ordinário.

68 Sobre o conceito de principios, remeta-se à obra de ALEXY, Robert. Theorie der Grundrechte..., p. 75-76, onde sustenta que principios são normas que expressam "mandamentos de otinizaçăo" (Optimierungsgebote), tendo em vista que ordenam que algo seja realizado na maior medida possivei, de acordo com as possibilidades juridicas e fáticas existentes, razão pela qual caracterizam-se pelo fato de poderem ser cumpridos em graus distintos, o que equivale dizer, realizarem-se em maior ou em menor grau.

ra Cf. REYES, Manuel Aragón. El Juez Ordinario entre Legalidad y Constitucionalidad..., p. 20; sobre a diferença fundamental entre "valor" e "princípio", vide ALEXY, Robert. Theorie der Grundrechte..., p. 133, quando sustenta que aquilo que no modelo dos valores é, prima facie, o melhor, é, no modelo dos principios, prima facie, devido. Por analogia, aquilo que no modelo dos valores é définitivamente o melhor é, no modelo dos principios, definitivamente devido. Essa constatação informa que os princípios e os valores diferenciam-se somente em virtude de seu caráter deontológico (proibiçăo, permissão e direito a algo) e axiológico (correspondente ao que é bom), respectivamente. E aqui surge, para Alexy, o ponto fundamental dessa diferenciação: como no Direito o que importa é o que é devido - e não simplesmente o que é bom - há uma nítida vantagem de se trabalhar com o modelo dos princípios (mandamentos de otimização), à medida que esse modelo expressa mais claramente o caráter do dever ser, diminuindo-se, conseqüentemente, a margem de falsas interpretaçôs. 
Faça-se, no entantoto, a anotação de que a necessidade de reconhecimento de uma autonomia das distintas esferas não implica um isolamento e, por assim dizer, uma incomunicabilidade entre elas ${ }^{70}$. Afinal, como consigna Konrad Hesse $^{71}$, a mudança das relações entre o direito constitucional e o direito privado ao longo da história expressa uma mudança das tarefas, da qualidade e das funções de cada um desses âmbitos jurídicos, o que afasta uma concepção de justaposição, marcada por uma absoluta incomunicabilidade entre esses âmbitos, para dar lugar a uma relação de complementaridade e dependência recíprocas.

Observe-se, também, que abordagem aqui sugerida não nega o efeito expansivo dos direitos fundamentais. Pretende-se, apenas, que tais direitos encontrem a sua melhor expressão e aplicação para as necessidades da sociedade, quando debatidos em um ambiente democrático, marcado pelo pluralismo de idéias e de visões, ambiente esse que não pode ser proporcionado pela jurisdição constitucional ${ }^{72}$. Sem a intermediação legislativa adequada, dificilmente a Constituição logrará êxito em sair da área do poder, para ingressar na esfera vital das convicções sociais, sem as quais não pode viver e às quais adere-se com calor ${ }^{73}$. O que, em última análise, se quer evitar, sāo os riscos do que Hans Peter Schneider ${ }^{74}$ denominou de uma fluidez descontrolada das normas da Constituição na interpretação do direito ordinário.

70 Aqui, cabe uma referencia aos escritos de RAISER, ludwig. O Futuro do Direito Privado. Traduzido por Lucinda Maria Ragugnetti. Revista da Procuradoria Geral do Estado do Rio Grande do Sul. Porto Alegre: PGE, ano 9, ก. 25, 1979. Traduçảo de: Die Zukunft des Privatrechts, p. 21, 25 e 29. Em que pese o autor discorter sobre una visualização do direito privado a partir de campos de função (nas suas palavras: "distinguir os campos de funçăo do Direito Privado, segundo o ctitério do conteúdo publicístico dos campos da vida a serem ordenados e a partir dai ordenar os princípios juridicos e as formas de funçäo dos institutos jurídicos" ${ }^{\prime \prime}$, a suá construçào toma-șe significativamente útil para o foco ora proposto, à medida que tal perspeciva coaduna-se com o espírito de comunicabilidade e de influências recíprocas que devem pautar as relações entre o direito constitucional e o direito ordinário. Nesse sentido, observem-se as palavras de Raiser: "se se procura um quadro que expresse a relação entre o direito privado e público dentro de nossa ordem jurídica global, entäo, depois do que foi dito, não se mostra apropriada a velha concepção de dois círculos fechados, interseccionando-se aqui e ali, mas também nảo é a proposta de Bullinger, err fundir ambos os círculos em um sistema unitario de direito comum. Mais de acordo com a realidade está o quadro de uma elipse com dois focos como centros de irradiaçāo, entre os quais aparece um campo intermediário, influenciado pelos dois centros. A força de irradiação de um ou de outro centro pode modificarse por meio de decisão política, mas o sistema seria destruído se um dos pólos perdesse sua força autônoma. Essencial é, ademais, a abertura e a necessidade de complementação das regras provindas de cada um dos pólos"; para uma análise aprofundada acerca da teoria de Ludwig Raiser e seus rofíxos sobre o direito privado, remeta-se à obra de CACHAPUZ, Maria Cláudiá. Intimidade e Vida Privada no Novo Código Civil Brasileiro. Uma leitura orientada no discurso jurídico. Porto Alegre: Sergio Antonio Fabris Editor, $2006, p$. 99-117.

7 HESSE, Konrad. Verfassungsrecht und Privatrecht..., p. 31, definindo que o ponto histórico marcante dessa nova realidade é o final da Primeira Guerra Murdial.

12 Cf. KELSEN, Hans. Wer soll der Hüter der Verfassung sein?..., p. 608, o tribunal constitucional năo foi criado para disputar a função legislativa com o legislador (duvidando, assim, que alguém espere que um tribunal constitucional venha a opor-se à expansão dessa competência legislativa de caráter geral').

73 Cf. ZAGREBELSKY, Gustavo. La Ley, el Derecho y la Constitución..., p. 22-23.74 SCHNEIDER, Hans Peter. Democracia y Constitucion..., p. 84.

74 SCHNEIDER, Hans Peter. Democracia y Constifucion..., p. 84. 


\section{Importância da função judicial}

A concepção até aqui esposada sublinha a circunstância de que a função judicial é uma das atividades públicas mais relevantes, sendo que a existência de direitos fundamentais diretamente aplicáveis, como, aliás, preconiza a Constituição Brasileira ${ }^{75}$, reforça o papel dos juízes em um Estado Democrático de Direito. Isso porque, se é verdade que os direitos fundamentais são diretamente aplicáveis, pelo fato de que a sua efetividade não pode ficar condicionada aos desejos de uma eventual maioria no órgão legislativo competente para a elaboração das leis ordinárias, não é menos verídico o fato de que tais direitos são, em vista de seu caráter genérico, algo muito distinto das normas infraconstitucionais. Ademais, em um sentido amplo, a aplicabilidade direta é um atributo dos direitos fundamentais que informa que eles devem ser entendidos como normas vinculativas e não como meras normas programáticas $^{76}$, o que constitui, de certa maneira, um elemento que bem expressa a relação estreita entre a unidade normativa da Constituição e esses direitos ${ }^{77}$.

Tal constatação revela que o campo da jurisdição constitucional na concretização dos direitos fundamentais alcança, invariavelmente, uma notável amplitude, o que acaba por proporcionar ao juiz, na condição de intérpreteaplicador da Constituição, uma ampla margem na hora de extrair dessas normas constitucionais o seu sentido ${ }^{78}$. É necessário, portanto, como advoga o jurista hispânico Manuel Aragón Reyes ${ }^{79}$, proclamar a adoção de medidas de reequilíbrio (curativas e preventivas, de contrapeso) e potenciar o normativismo, de forma a reduzir a jurisprudência de valores ${ }^{80}$. Esse é o caminho, na acepção do referido autor, para que o Estado Democrático de Direito não acabe

75 Segundo o artigo $5 .^{\circ}, \S 11^{\circ}$ da Constituição Brasileira, "as normas definidoras de direitos e garantias fundamentais têm aplicação imediata".

76 Quanto ao conceito de "programa da norma" remeta-se à HESSE, Konrad. Elementos de Direito Constifucional da República Federal da Alemanha..., p. 64-65.

7 Cf. HECK, Luís Afonso. O Controle Normativo no Direito Constitucional Brasileiro..., p. 64.

78 Esse é o raciocínio exposto por REYES, Manuel Aragón. El Juez Ordinario entre Legalidad y Constitucionalidad..., p. 30.

79 REYES, Manuel Aragón.EI Juez Ordinario entre Legalidad y Constitucionalidad..., p. 30-31, destacando, ainda, que a excessiva jurisdicionalização da política conduz, necessariamente, à politização da justiça, situação altamente indesejada (p. 40).

so A propósito, como salienta ALEXY, Robert. Theorie der Grundrechte..., p. 26, aquilo que em cada caso é concebido como juridico depende de uma análise que ultrapassa o Âmbito de abrangência da jurisprudencia dos valores. Destaca o autor, com essa observação, a importância de a ciência do Direito vincular, reciprocamente, as três dimensóes da dogmática jurídica: a analítica, a empírica e a normativa (para maior detalhamento, remeta-se às p. 22-27 da citada obra). Nessa conectividade, Alexy destaca a dificuldade de construçăo de uma argumentação jurídico-fundamental relativa a simples associaçōes ao conceito de valor (p. 33), sustentando, para tanto, o imperativo de se adotar uma clareza terminológica no que diz respeito à concepção dos direitos fundamentais e, de certo modo, a todos os conceitos da dogmática de direitos fundamentais, no instante em que se nāo existir uma clareza acerca da estrutura desses direitos, nảo será possivel, em decorrencia, obter uma clareza na sua fundamentaçăo (p. 34), tendo em vista que o pressuposto de racionalidade de toda ciência é a claridade conceitual, a ausência de contradiçăo e a coerência ( $p$. 27). 
convertendo-se em um Estado de justiça; aquele marcado pela busca de certeza, previsão, segurança, igualdade e liberdade nas relações sociais; esse, expressão do caldo de cultivo da arbitrariedade e da desigualdade ${ }^{81}$. Tal como propôs Francisco Rubio Llorente ${ }^{\mathrm{B2}}$, a lei deve ser vista como garantia dos direitos, pelo fato de que "é o único cimento firme da segurança jurídica".

É importante frisar que esse sentimento de valorização do direito ordinário frente à Constituição não é tão radical a ponto de não se reconhecer que a criação judicial de regras jurídicas - devidamente fundamentadas ${ }^{23}$ pode vir a ser necessária, em circunstâncias extremas, para satisfazer, no caso vertente, uma pretensão fundada em direitos reconhecidos por normas constitucionais de caráter principiológico ${ }^{84}$. Trata-se da hipótese de inexistência de regras legislativas ${ }^{85}$ em conformidade com tais princípios, cujo resultado pode ser o esvaziamento de certos direitos reconhecidos na Constituição. Nesse caso, reconhece-se a competência dos tribunais para responder, com o auxílio dos métodos de interpretação reconhecidos ${ }^{86}$, na aplicação concreta, às questões duvidosas surgidas pela ausência de uma regulação expressa ${ }^{87}$.

O resultado dessa ponderação é que a atividade judicante não se configura apenas no reconhecimento e na expressão de certas decisöes do legislador; antes pelo contrário, compreende-se na tarefa do Poder Judiciário a possibilidade de "exigir o trazer à luz e o realizar em decisões de representações

81 Cf, REYES, Manuel Aragón. El Juez Ordinario entre Legalidad y Constitucionalidad..., p. 31.

3. LLORENTE, Francisco Rubio. La Forma del Poder. Estudios sobre la Constitución..., p. 334.

33 Está-se, aqui, diante de matéria concemente ao campo da argumentaçăo juridica. Nesse particular, remetase a ALEXY, Robert. Theorie der juristischen Argumentation. Die Theorie des rationalen Diskurses als Theorie der juristischen Begründung..., p. 163, quando afirma que a tarefa da teoria do discurso jurldico corresponde à investigação de como se pode argumentar racionalmente sob condições limitadoras e de como se pode melhorar a possibilidade de uma argumentaçäo racional sob tais condiçóes, sendo que o objeto da teoria da argumentaçâo juridica é o tratamento de questões práticas concretas (p. 132, nota 296).

B4 Prova disso é que, segundo ALEXY, Robert. Theorie der Grundrechte..., p. 63, uma norma de direito fundamental somente poderá ser considerada como tal, à medida que possa ser passivel de uma fundamentaçăo juridico-fundamental correta.

s: Conforme noticia HECK, Lús Afonso. O Tribunal Constitucional Federal e o Desenvolvimento dos Princípios Constitucionais. Contributo para uma compreensão da jurisdição constitucional federal alemã..., p. 209, aqui baseado na jurisprudencia do tribunal constitucional Federal alemão, a pressuposiçăo de ausência de lacunas na ordem juridica positiva representa uma condiçăo que, como postulado da certeza jurídica é justificável, porém, inalcançável ná práticà.

B6 Fundamental, aqui, como destaca ZlPPELUUS, Reinhold. Teoria Geral do Estado. Traduzido por Karin PraefkeAires Coutinho. Lisboa: Fundaçăo Galouste Gulbenkian, 1997. Traduçăo de: Aligemeine Staatslehre, p. 66 , é levar a efeito um método de interpretaçăo que se adapte às circunstáncias dominantes, o que, logicamente, só pode vir a ser determinado no caso concreto.

87 Cf. HECK, Luís Afonso. O Tribunal Constitucional Federal e o Desenvolvimento dos Princípios Constitucionais. Contributo para uma compreensão da jurisdição constifucional federal alemã..., p. 209 e ss., oportunidade em que discorre sobre a experiencia alemã, no que tange aos îmites de admissibilidade de uma "aplicação jurídica criadora". 
de valores" que não - ou apenas incompletamente - chegaram à expressão nos textos das leis escritas ${ }^{88}$. É de bom alvitre, portanto, que frente a essa perspectiva de caráter excepcional, o juiz, com todas as suas forças, preservese da arbitrariedade, o que pode ser constatado quando a decisão repousa sobre uma argumentação racional" ${ }^{89}$, cerrando, assim, "a lacuna consoante com os critérios da razão prática e as representações de lustiça gerais consolidadas da coletividade ${ }^{\prime \prime 90}$. Todavia, ainda que se aceite tal possibilidade, não há como se iludir acerca da sua descomprometida aplicação ${ }^{91}$, no instante em que encerra em si um inegável perigo, qual seja, o de que o quadro de princípios constitucionais venha a cristalizar-se em detrimento da apreciação política do legislador, fato que, como já indicado, é altamente indesejável ${ }^{92}$.

sa Cf. HECK, Luís Afonso. O Tribunal Constitucional Federal e o Desenvolvimento dos Princípios Constitucionais. Contributo para uma compreensão da jurisdição constitucional federal alemã..., p. 210 , com arrimo na jurisprudência do Tribunal Constitucional Federal alemão.

Q9 A respeito desse tema, fundamental a leitura de ALEXY, Robert. Theorie der juristischen Argumentation. Die Theorie des rationalen Diskurses als Theorie der juristischen Begründung..., p. 358-359, onde, em passagem conclusiva, 0 autor assevera que a teoria do discurso racional como teoria da fundamentaçăo juridica óerece, em situaçöes especificas, una espécie de critério (Kriterium) que pode contribuir substancialmente para a racionalização dos processos de decisão e, conseçüentemente, para a racionalização das decisões deles derivados. Adverte, entretanto, que no âmbito juridico, em que pese poderem os juristas, por meio da prática de um discurso racional, contribuir para a realização da razāo (Vernunft) e da justiça (Gerechtigkeit), não podem fazê-lo isoladamente, eis que tal meta pressupóe uma ordem social racional e justâ.

90 Cf. HECK, Luís Afonso. O Tribunal Constitucional Federal e o Desenvolvimento dos Princípios Constitucionais. Contributo para uma compreensão da jurisdição constitucional federal alemä..., p. 210, com arrimo na jurisprudencia do Tribunal Constitucional Federal alemão.

ys Conforme anuncia HECK, Luís Afonso. O Tribunal Constitucional Federal e o Desenvolvimento dos Principios Constitucionais. Contribưto para uma compreensão da jurisdição constifucional federal alemã..., p. 212-213, os Iimites da chamada aplicaçăo jurídica criadora, de acotdo com a experiência consiitucional alemã (com remissö́es à jurisprudência), conquanto não possam ser configurados em uma formula que possa valer, na mesma medida para todos os setores jurídicos, traduzem algumas caracteristicas comuns, que, parcialmente, seguem aqui citadas: 1. "A aplicação juridica criadora deve realizar-se no interior do traçado limite constitucional. Ela não constitui a manifestaçäo do inadmissivel esbutho judicial, por meio do qual a vontade reconhecivel do legislador é afastada e substitufda por uma avallaçăo judicial de interesses, feita de forma autárquica. Antes, as questōes, se há uma lacuna e por qual modo ela deve ser cerrada, săo tomadas das vatorizaçôes da lei"; 2 . "No caminho da interpretação não deve ser atribuído um sentido oposto a uma lei, pelo teor e pelo sentido, clara. Na possibilidade de várias interpretaçöes, deve, na dúvida, ser eleita aquela que confere à nom de direitos fundamentais a eficácia máxima. Em intervençöes particularmente intensivas nalgum dos direitos protegidos pela Constituição, certos erros de interpretação já podem mostrar.se como constitucionalmente relevantes, ou seu caminho metodologicamente falso pode ser objetado, também quando o próprio resultado está consoante com a Constituição".

92 Essa constatação, em sua integralidade, é retirada da obra de ZAGREBELSKY, GuStavo. El Derecho Dúctil. Ley, Derechos, Justicia..., p. 152-153, destacando o risco de excesso de juridicizaçāo e constitucionalizaçāo da vida política. Para Zagrebelsky, esse perigo não ocorre quando os juizes ordinários fazem á derivação da regra (criaçäo judicial de regras jurídicas), cuja jurisprudencia pode ser superada por uma diferente vałoração do legislador, no marco das possibilidades constitucionais. 
Com isso - cumpre registrá-lo - não se adere à tese de que o legislador ordinário deva ter uma irrestrita margem de conformação dos direitos fundamentais e dos valores consagrados pela Constituição ${ }^{93}$. Se isso fosse possível, estar-se-la abrindo a possibilidade de uma eventual supressão desses direitos e valores, por força dos interesses de uma maioria de ocasião (por meio da lei). É o que se poderá afirmar, na esteira de Konrad Hesse ${ }^{94}$, em relação ao fato de que o significado do direito constitucional para o direito privado consiste em "singulares funções de proteção, direção e impulso". Assume relevo, portanto, a devida compreensão do papel fundamental de um tribunal constitucional ${ }^{95}$ no ordenamento jurídico, qual seja, o de verificar se o legislador, no curso de sua atividade legiferante, interpretou corretamente o conteúdo de um direito constitucionalmente declarado ${ }^{96}$, ou seja, aferir se o legislador fixou, em harmonia com a Constituição vigente, os contornos que delimitam o âmbito da proteção jurídica conferida pela Constituição ${ }^{9 \%}$.

De resto, não se pode perder de vista que o juiz tem que saber o que se passa no plano constitucional para aplicar as regras de direito ordinário; entretanto, como bem destaca Robert Alexy ${ }^{98}$, a ciência do Direito é, antes de tudo, uma disciplina prática, pelo fato de que a sua questão nuclear é a busca do que é devido nos casos reais ou imaginários, de modo que aquilo que é devido, e em que medida é devido, descobre-se a cada vez, no caso concreto ${ }^{99}$. Essa construção assume relevo pelo fato de que as normas constitucionais, em função de seu alto grau de abstração e abertura, não são capazes de, por si só,

9.3 Adere-se, aqui, à ponderação de SARLET, Ingo Wolfgang. A Eficácia dos Direitos Fundamentais..., p. 328, no seguinte sentido: se, por um lado, apenas o legislador encontra-se autorizado a estabelecer restriçoes aos direitos fundamentais, por outro, ele próprio encontra-se vinculado a eles.

94 HESSE, Konrad. Verfassungsrecht und Privatrecht..., p. 40. Confira-se o original em língua alemã: Demgemäß liegt die Bedeutung des Verfassungsrechts für das Privatrecht in 'einzelnen' Schutz-, Richtlinien- und impulsfunktionen.

95 A propósito, nesse particular, vide HESSE, Konrad. Elementos de Direito Constitucional da República Federal da Alemanha..., p. 422, quando afirma que o poder do tribunal constitucional - e, por assim dizer, o seu próprio prestígio - depende da força dos argumentos empregados nas suas decisões.

96 Cf. PIEROTH, Bodo; SCHLINK, Bernhard. Grundrechte Staatsrecht Il..., Rdn. 929, p. 229, o espaço de conformação do legislador é delimitado pela jurisprudência do Tribunal Constitucional Federal alemão sob diferentes aspectos, que, em comum, constituem manifestaçōes do princípio da proporcionalidade.

97 Cf. MARTÍNEZ-PUIALTE, Antonio Luis. La Garantia del Contenido Esencial de los Derechos Fundamentales..., p. 79-80, sugerindo, ainda, que a adequação da interpretaçăo legislativa à Constituição e tarefa a ser dada a um tribunal constitucional, em face da sua competencia para fixar de maneira definitiva o sentido dos preceitos constitucionais e, concretamente, o conteúdo dos direitos fundamentais.

98 ALEXY, Robert. Theorie der Grundrechte..., p. 26.

99 Essa consideração evidencia-se pelo fato de que, no âmbito da análise de direitos fundamentais, nada poderá ser definido de antemão, pelo simples fato de que não existirá uma única resposta correta pała todos o5 casos. Para tanto, remeta-se às considerações de ALEXY, Robert. Theorie der juristischen Argumentation. Die Theorie des rationalen Diskurses als Theorie der juristischen Begründung..., p. 433, quando afirma que a teoria do discurso jurídico racional não pressupōe que exista uma única resposta correta para todos os casos, ou seja, a argumentaçảo jurídica não conduz em todos os casos exatamente a um só resultado, não se cogitando, portanto, em uma irrestrita pretensāo de correçăo das decisões judiciais. 
na maioria dos casos, informar essa medida do que é devido em concreto, razão pela qual o direito ordinário assume um valioso e indispensável papel nesse particular, no momento em que permite, com um grau de abstração significativamente menor em relação ao das normas constitucionais - e por isso mais eficazmente - desenvolver e dar forma às relações vitais garantidas pela Constituição ${ }^{100}$, enquanto decisão normativa que é o produto, em cada momento, do jogo legítimo do pluralismo político ${ }^{101}$. Enfim, como sintetiza Robert Alexy ${ }^{102}$ : "para poder dar uma resposta ao que é o juridicamente devido, há que se conhecer o direito positivamente vigente".

Em outras palavras, o tribunal constitucional tem a missão - e, por assim dizer, o dever - de verificar se a concreção valorativa realizada pelo legislador ordinário pode ser inserida dentro dos critérios valorativos consagrados pela Constituição, por meio dos meios processuais oferecidos pelo ordenamento jurídico.

\section{A primazia do legislador na concretização da Constituição}

Ao direito ordinário incumbe, pois, a tarefa de transformar os princípios consagrados na Constituição em instrumentos concretos de ação ${ }^{103}$, desempenhando as cláusulas gerais ${ }^{104}$ de conteúdo indeterminado do direito civil (ex: boa-fé, probidade, função social do contrato, etc.) um papel de destaque nessa conectividade, enquanto técnica legislativa eficaz no sentido de permitir e facilitar a inserçāo dos valores constitucionalmente estabelecidos no corpo do direito civil codificado ${ }^{105}$.

Isso significa que a um tribunal não é dado, ao menos em princípio, diminuir posições jurídicas que o legislador prolongou sob a concretização de princípios constitucionais gerais ${ }^{106}$, a menos, é claro, se no caso concreto ${ }^{107}$

(1) Cf. HESSE, Konrad. Verfassungsrecht und Privatrecht..., p. 42, ao interpretaro significado do direito privado para a ordem constitucional. ${ }^{101}$ Cf. REYES, Manuel Aragón. El Juez Ordinario entre Legalidad y Constitucionalidad..., p. 37.

${ }_{102}$ ALEXY, Robert. Theorie der Grundrechte..., p. 27, em traduçâo livre do autor. Confira-se a assertiva original, em lingua alemá: Um eine Antwort auf die Frage, was rechtlich gesollt ist, geben zu Können, muß man das positiv gettende Recht kemnen.

103 MARTINS-COSTA, Judith. O Novo Código Civil Brasileiro: em Busca da "Ética da Situação". In: MARTINSCOSTA, Judith; BRANCO, Gerson Luiz Carlos. Diretrizes Teóricas do Novo Código Civil Brasileiro. São Paulo: Saraiva, 2002, p. 144.

304 Para uma visāo sobre a o papel das cláusulas gerais do direito civil, vide, por todos, HECK, Luís Afonso. In: CACHAPUZ, Maria Cláudia. Intimidade e Vida Privada no Novo Código Civil Brasileiro. Uma leitura orientada no Discurso Jurídico. Porto Alegre: Sergio Antonio Fabris Editor, 2006 (prefácio), p. 15-29. Cf. SILVA, Luis Renato Ferreira da. A Funçäo Social do Contrato no Novo Código Civil e sua Conexão com a Solidariedade Social. In: Ingo Wolfgang Sarlet (org), O Novo Código Civil e a Constituição. Porto Alegre: Livaria do Advogado, 2003, p. 129.

$1 \%$ Cf. HECK, Luís Afonso. O Tribunal Constitucional Federal e o Desenvolvimento dos Princípios Constitucionais. Contributo para uma compreensão da jurisdição constitucional federal alemã..., p. 213.

wa Está-se, aqui, diante de uma relação de ponderação que somente um discurso jurídico racional, marcado por uma argumentação jurídico-fundamental, pode definir. Nesse sentido, vide ALEXY, Robert. Theorie der juristischen Argumentation. Die Theorie des rationalen Diskurses als Theorie der juristischen Begründung..., p. 147, quando destaca a necessidade de obtenção de um consenso fundado nas decisöes judiciais, ou seja, um consenso que se baseia na força do melhor argumento. 
constatar-se que a concretização legislativa implica intervenção nos direitos fundamentais que onera demasiadamente o seu respectivo titular, de forma a violar a proibição de excesso; e, por outro lado, se a lei em questão situa-se aquém do mínimo que a Constituição oferece para a proteção da outra parte ${ }^{108}$. Assim, em muitos casos, por um imperativo de dever de proteção (Schutzpflicht) do Estado ${ }^{109}$, torna-se necessária a prática de intervenções em posições protegidas jurídico-fundamentalmente, cabendo ao legislador a definição de uma compensação proporcional ${ }^{110}$. Deveras, o próprio modo pelo qual esse dever de proteção do Estado deve ser cumprido é um aspecto a ser definido pelo legislador, em princípio, com uma considerável liberdade de decisão (Entscheidungsfreiheit) ${ }^{111}$.

Evidencia-se, assim, que garantir a influência dos direitos fundamentais sobre o direito ordinário, como parte da ordem jurídica total, é, em primeiro lugar, uma tarefa do legislador infraconstitucional, a quem cabe configurar a ordem da coletividade e, na organização e limitação dos direitos fundamentais, determinar o seu alcance prático ${ }^{112}$. Compete ao legislador, portanto, no curso de sua atividade conformadora, concretizar o conteúdo jurídico desses direitos, demarcando, reciprocamente, as posiçōes dos sujeitos privados garantidas jurídico-fundamentalmente ${ }^{13}$. Dito de outro modo, cabe ao legislador a tarefa de determinar o equilíbrio entre o respeito à liberdade individual e à vigência efetiva dos direitos fundamentais ${ }^{114}$. A maior prova dessa constatação é que a própria noção de dignidade humana - um dos conceitos jurídicos de maior abertura e indeterminação - realiza-se, como agudamente consigna Peter

:OB Cf. CANARIS, Claus-Withelm. Grundrechte und Privatrecht. Eine Zwischenbilanz. Berlin - New York: Walter de Gruyter, 1999, p. 19-20, demonstrando que entre esses dois pontos (funça de mandamentos de proteçăo - Schutzgebote - dos direitos fundamentais e proibição de excesso - Übermaßverbot) existe, via de regra, um largo espaço de manobra (Spielraum), dentro do qual não é determinada a solução jurídicoconstitucionalmente ta cujo preenchimento, por isso, é deixado a cargo do direito ordinário.

De acordo com a acepção de HESSE, Konrad. Elementos de Direito Constitucional da República Federal da Alemanha..., p. 278 , a teoria dos deveres de proteção do Estado parte da compreensão dos diretos fundamentais como princípios objetivos que obrigam o Estado a agir, na medida do possível, para a realização dos direitos fundamentais; vide, ainda, ALEXY, Robert. Theorie der Grundrechte..., p. 410, sustentando, a partir dai, a existência de "direitos à proteção" (Rechte auf Schutz) os quais devem ser entendidos como todo e qualquer direito que um titular de direito fundamental possui frente ao Estado, para que esse o proteja das intervencōes (indevidas) de terceiros. Entre nós, vide SARLET, Ingo Wolfgang. A Eficácia dos Direitos Fundamentais..., p. 329, sustentando que o legislador possui deveres ativos de proteçäo, que englobam um dever de aperfeiçoamento (Nachbesserungspflicht) da legislação existente, com á finalidade de conformá-la às exigências das normas de direitos fundamentais.

1:0 Cf. HESSE, Konrad. Elementos de Direito Constitucional da República Federal da Alemanha..., p. 280.

is Cf. PIEROTH, Bodo; SCHLINK, Bernhard. Grundrechte Staatsrecht II..., Rdn, 91, p. 25.

$12^{2}$ Cf. HESSE, Konrad. Elementos de Direito Constitucional da República Federal da Alemanha..., p. 424.

17.3 Cf. HESSE, Konrad. Elementos de Direito Constitucional da República Federal da Alemanha..., p. 285.

114 Cf. Al.FARO AGUILA-REAL, Jesús. Autonomia Privada y Derechos Fundamentales. In: Anuário de Derecho Civil. Madrid, tomo XLVI, fascículo 1, jan. - már. 1993, p. 65. 
Häberle"1: de "baixo para cima" (von unten nach oben) - e não de "cima para baixo", no instante em que a ordem jurídica infraconstitucional exerce uma indispensável mediação, no sentido de fornecer material para a delineação do contorno dos bens constitucionais.

Essa destacada função do direito ordinário revela a importância de se manter, na medida do possível, a validez da lei para a sua correta interpretação em conformidade com os ditames da Constituição. Por essa razão, pode-se defender, ao menos em princípio, a primazia do legislador na concretização da Constituição, o que equivale a dizer que o legislador democraticamente eleito goza da presunção de constitucionalidade da sua vontade e atuação ${ }^{116}$. Isso significa, na prática, uma atitude hermenêutica ${ }^{117}$ voltada à preservação da lei, algo como um favor concedido à lei: se a lei pode ser interpretada de duas maneiras, uma contrária e outra conforme a Constituição, que seja mantida na interpretação que guarda sintonia com a Constituição, ao invés de, simplesmente, ser retirada do mundo jurídico. Nesse desiderato, impōe seja ressaltada a observação de Konrad Hesse ${ }^{118}$, no sentido de que o tribunal constitucional não pode disputar a primazia da concretização da Constituição com o legislador, causando, caso o faça, uma remoção das funçōes atribuídas jurídico-constitucionalmente ao Poder Legislativo. Há, contudo, um ponto de equilíbrio a ser observado e esse passa a ser demonstrado a partir da transcrição literal do pensamento de Hesse ${ }^{19}$ :

[...] a primazia do legislador democrático é obtida com o preço de uma nova interpretação do conteúdo da lei pelo Tribunal Constitucional; ela pode ficar sem valor se o preço ficar muito alto, se o conteúdo, que o tribunal, em interpretação conforme a Constituiçăo, dá à lei, não mais contém um minus, senão um aliud diante do conteúdo da lei primitivo. Neste caso, o tribunal intervém até mais intensamente nas faculdades do legislador do que em uma declaração de nulidade, porque ele próprio configura positivamente quanto ao conteúdo, enquanto a nova configuração, na declaração de nulidade, permanece objeto do legislador. Quanto mais o tribunal corrige

11.5 HÄBERLE, Peter. Die Menschenwürde als Grundlage der staatlichen Gemeinschaft. In: ISENSEE, Josef; KIRCHHOF, Paul. (Hrsg.). Handbuch des Staatsrechts der Bundesrepublik Deutschland. 3. Auflage. Heidelberg: C. F. Müller Juristischer Verlag GmbH, Band II, 2003, Rdn, 83, p. 358.

116 Assimo defende HESSE, Konrad. Elementos de Direito Constitucional da República Federal da Alemanha..., p. 73, aduzindo que ao legisłador democrático está encarregada a tarefa da configuração jurídica das condiçoes da vida, em primeiro lugar.

1:7 De acordo com a lição de GADAMER, Hans-Georg. Warheit und Methode. Grundzüge einer philosophischen Hermeneutik..., p. 340, a exigencia hermeneutica consiste em compreender a manifestaçăo contida em um texto, a partir da situação concreta na qual foi produzido.

118 HESSE, Konrad. Elementos de Direito Constitucional da República Federal da Alemanha..., p. 73.

119 HESSE, Konrad. Elementos de Direito Constitucional da República Federal da Alemanha..., p. 73-74. 
o legislador, tanto mais ele também se aproxima dos limites jurídico-funcionais da interpretação conforme a Constituição, que decerto dificilmente podem ser traçados com toda nitidez.

Não há, portanto, ao menos no que tange à interpretação da Constituição, diferenças facilmente assimiláveis entre o exercício de esforço interpretativo levado a efeito pelo legislador ordinário e pelo tribunal constitucional' ${ }^{120}$.

Para comprovar tal assertiva, basta colocar-se no lugar de um, ou de outro, diante da compreensão ${ }^{123}$, ainda que os respectivos âmbitos de atuação sejam claramente distintos. Se aquele falha, cabe a esse informá-lo como deve interpretar a Constituição, importa dizer, o tribunal constitucional informa ao legislador como ele deve conformar uma dada realidade, em consonância com os valores consagrados pela Constituição ${ }^{122}$; informa, em última análise, como o legislador deve interpretar a Constituição. Nessa quadra, um dos maiores desafios para quem se ocupa da relação entre as jurisdições constitucional e ordinária é reconhecer, efetivamente, que o legislador ordinário tem a importante função de desenvolver os direitos constitucionalmente reconhecidos, interpretando, aplicando ${ }^{123}$ e concretizando o seu respectivo conteúdo, estabelecendo, assim, as condiçōes que façam possível seu mais pleno exercício efetivo pelos cidadãos. Deve haver, como salienta Robert Alexy ${ }^{124}$, uma verdadeira relação de cooperação autêntica entre a jurisdição constitucional e a jurisdição especializada. Nesse cenário, a atuação do legislador converte-se,

120 Cf. KELSEN, Hans. Wesen und Entwicklung der Staatsgerichtsbarkeit..., p. 31-33, ressaltando que como a Constituiçăo determina, no essencial, a elaboraçăo das leis, a legislaçăo é, perante a Constituição, aplicação do Direito (p. 32).

121 Cf. GADAMER, Hans-Georg. Warheit und Methode. Grundzüge einer philosophischen Hermeneutik..., p. 308, também impera uma exigência hermenêutica, que consiste no fato de se ter que se colocar no lugar do outro para poder compreendê-lo. Em outra passagem, Gadamer sustentá que é elogiável a compreensão de alguém quando, ao julgar, desloca-se completamente para a plena concreção da situação em que o outro deve atuar (p. 328),

122 De acordo com a acepção de KELSEN, Hans. Wesen und Entwicklung der Staatsgerichtsbarkeit..., p. 30, a jurisdição constitucional é uma garantia judicial da Constituição, como elo no sistema de medidas técnicojurídicas que têm por finalidade assegurar o exercicio das funçöes estatais em conformidade com o Direito. Nesse quadro, é inegável que o tribunal constitucional tem a função precípua de verificar a conformidade ao Direito (Rechtmässigkeit) das funçöes estatais. Evidencia-se, portanto, que cada ordenamento juridico deverâ eleger, ao seu tempo, os valores que serão plasmados na Constituiçăo, os quais, por sua vez, deverão servir de paràmetro para a atividade legiferante.

${ }^{123} \mathrm{Cf}$. anuncia GADAMER, Hans-Georg. Warheit und Methode. Grundzüge einer philosophischen Hermeneutik..., p. 312-313, quanto mais claro é o conceito, mas clara é a explicaçăo, no instante em que o compreender (Verstehen) é sempre um interpretar, razão pela qual a interpretaçăo (Auslegung) é a forma explícita da compreensão. Disso depreende-se que direitos fundamentais, interpretaçăo e aplicaçāo são realidades que estão sempre interligadas, tendo em vista que na compreensão sempre ocorre algo como una aplicação do texto a ser compreendido à situação atual do intérprete.

${ }^{124}$ ALEXY, Robert. Direito Constitucional e Direito Ordinário. Jurisdição Constitucional e Jurisdição Especializada. Tradução de Luís Afonso Heck. Revista dos Tribunais. Sảo Paulo: Revista dos Tribunais, n. 809 , ano 92 , mar. 2003, p. 72 . 

fundamentais ${ }^{125}$.

Se, como ponderou Georg Jellinek ${ }^{126}$, a tarefa da ciência humana é, essencialmente, construir, há que se resistir, portanto, à tentação de se acreditar que apenas e tão somente as leis devam ser interpretadas a partir da Constituição ${ }^{127}$, pois tal concepção padece do vício do extremismo. Ocorre que se tal vertente é correta - no instante em que não se questiona que as leis devam ser interpretadas em conformidade com a Constituição - também procede que a Constituição deva ser interpretada a partir da lei, pois esse agir confirma a correlação estreita que existe entre a Constituição e a lei, traduzindo, com isso, a idéia da unidade da ordem jurídica ${ }^{128}$. Aqui, o compreender e o interpretar significam conhecer e reconhecer um sentido vigente, de modo que se não compreendermos o sentido do direito ordinário, reconhecendo a sua importância na concretização de princípios constitucionais, não nos será possível interpretar e aplicar a Constituição, à medida que faltará ao intérpreteaplicador esses elementos nucleares para a prática de uma mediação jurídica entre a lei e a Constituição ${ }^{129}$.

Merece ser encarada com certa ressalva, portanto, a assertiva proposta por Jorge Miranda ${ }^{130}$, no sentido de que "não é a Constituição que deve ser interpretada em conformidade com a lei, mas sim a lei que deve ser interpretada em conformidade com a Constituição". Ainda que a afirmação de Jorge Miranda encontre eco na doutrina, o fato é que não há como desconsiderar, sob pena de se omitir um aspecto fundamental à compreensão do sentido da relação entre a supremacia da Constituição e a importância do direito ordinário, que o

25 Esse e pensamento de MARTÍNEZ PUJALTE. Antonio Luis, La Garantia del Contenido Esencial de los Derechos Fundamentales..., p. 141, ponderando, ainda, que a atuaçăo do legisiador deve desenvolver «se no marco do mais seleto respeito ao conteúdo dos direitos fundamentais constitucionalmente declarado.

3.6 JELLNEK, Georg. System der Subjektiven Öffentlichen Rechte. 2. Auflage. Tübingen: J. C. B. Mohr (Paul Siebeck), 1919, p. 12.

327 Nesse sentido, remela-se ao magistério de KEISEN, Hans. Wer soll der Hüter der Verfassung sein?..., p. 589, quando sustenta que, de modo geral, a maioria das decisöes dos processos são decisóes de dúvidas e diferenças de opiniảo sobre o conteúdo de uma determinaçăo legall, de modo que é impossivel afirmar que a incerteza do conteúdo de uma noma constitucional é algo diferente da incerteza que ocorre em relação a uma norma que não possui o caráter de normà constitucional.

328 Essa é a referência trazida por HESSE, Konrad. Elementos de Direito Constitucional da República Federal da Alemanha..., p. 75, quando afirma que a "interpretação conforme a Constitução de leis é, por conseguinte, em sua repercussảo sobre a interpretaçăo constitucional, interpretação conforme a lei da Constituição".

:29 Aqui se colne inspiração em GADAMER, Hans-Georg. Warheit und Methode. Grundzüge einer philosophischen Hermeneutik..., p. 333, quando demonstra que a interpretação exige o reconhecimento do objeto, ou seja, do texto dotado de autoridade, já que se deve reconhecer o significado jurídico da lei. Com isso, concluimse que não se pode passar por cima do direito ordinário, em toda e qualquer situação, mediante uma aplicação direta da Constituição para a soluçăo de controvérsias.

:30 MIRANDA, Jorge. Manual de Direito Constitucional. 3.ed. Coimbra: Coimbra Editora, 1996, Tomo ll, p. 261, embora registre que "na interpretaçăo de preceitos da Constituição, é legitimo e pode ser conveniente considerar o modo como são aplicados na prática, em especial através da lei e das decisóes dos tribunais". 
tribunal encarregado de exercer a jurisdição constitucional, ao interpretar a lei, interpreta a Constituição a partir da lei, ou seja, no momento em que interpreta a lei, verifica como o legislador ordinário interpretou a Constituição, de forma que a jurisdição constitucional pode, com base na Constituição - e com as devidas cautelas - intervir na legislação ordinária em nome do bem comum $^{13}$, para realizar uma legítima conformação dos valores esculpidos na Constituição, em o que se poderia denominar, ao menos pela idéia que transmite, de uma relação de diálogo entre as fontes ${ }^{132}$, cujo mecanismo pode ser sintetizado da seguinte forma: à medida que os valores constitucionais abstratos depuram o Direito, eles elevam o nível jurídico das normas de direito ordinário e da jurisprudência. Com o tempo, vai surgindo um Direito mais justo que, por sua vez, depura os valores da Constituição, em um ciclo contínuo de aperfeiçoamento ${ }^{133}$. Em suma, a influência do direito constitucional sobre o direito ordinário encontra-se, sobretudo, no plano do seu aperfeiçoamento e desenvolvimento ${ }^{134}$.

Logo, sem legislação ordinária, não há falar em um adequado desenvolvimento dos direitos fundamentais e, mais do que isso, em uma

131 A propósito, registre-se a definição de bem comum proposta por SOUZA JUNIOR, Cezar Saldanha. (Informaçăo oral). Aulas de Teoria de Direito Público do Curso de Pós-graduação em Direito da Universidade Federal do Rio Grande do Sul, $1 .{ }^{\circ}$ semestre de 2005: "o bem de todos naquilo que todos temos em comum"; com base nos ensinamentos de GADAMER, Hans-Georg. Warheit und Methode. Grundzüge einer philosophischen Hermeneutik..., p.295, revela-se, contudo, que no plano jurídico, e com base na teoria hermeneutica, esse bem comum deve ser visto e definido a cada vez, à medida que o compreender em si deve ser pensado não tanto como uma ato da subjetividade, mas mais como uma inserção em um acontecimento da tradição, onde há uma mediação (Vermittlung) constante entre o passado e o presente, o que afasta a existência, nesse sentido, de um bem comum aptioristico. Gadamer sustenta, nesse passo, que aquilo que é bom para o homem se dá a cada vez, na concretização da situação prática na qual ele se encontra (p. 318). Com isso, Gadamer sublinha a importância do conjunto da tradiçăo histórica para a interpretação do direito constitucional - e aqui se entende que, sobretudo, para a determinação do bem comum - em face da necessidade de se manter o conjunto da tradição aberto para o futuro (p. 346).

132 O termo "diálogo" é sugerido por SOUZA JUNIOR, Cezar Saldanha. Direito Constitucional, Direito Ordinário, Direito Judiciário..., p. 12, especialmente quando afirma que "o fundamento do direito está, isso sim, nos alicerces do ordenamento, ou seja, na realidade ontológica da pessoa, da familia e da vida social ordinária. Daí vai subindo, em instâncias críticas e de diálogo, pela via do direito legistado, até a cúpuła do ordenamento, de onde, enriquecida e descortinando o todo, pode realimentar o diálogo circular hermeneutico, que recomeça nas bases do ordenamento"; a expressäo "diálogo entre as fontes" credita-se a MARQUES, Claudia Lima. Superação das Antinomias pelo Díalogo das Fontes: o modelo brasileiro de coexistência entre o Código de Defesa do Consumidor e o Código Civil de 2002. Revista de Direito do Consumidor. São Paulo: Revista dos Tribunais, n. 51, jul-set de 2004, p. 57, quando afirma que "diálogo pressupõe o efeito útil de dois (di) e uma lógica ou fala (logos), enquanto o 'conflito' leva à exclusăo de uma das leis e bem expressa a mono-solução ou o 'monólogo' de uma só lei". Segundo a autora, o díálogo representa um esforço na busca de novas soluçöes de carater plural, com as quais visa-se a evitar antinomias pela correta deftnição dos campos de aplicação das normas.

133 Trata-se da perspectiva levantada por SOUZA JUNIOR, Cezar Saldanha. (Informaçăo orai). Aulas de Teoria de Direito Público do Curso de Pós-graduação em Direito da Universidade Federá do Rio Grande do Sul $10^{\circ}$ semestre de 2005.

${ }_{134}$ Esssa é a lição trazida por HECK, Luís Afonso. Direitos Fundamentais e sua Influência no Direito Civil. Revista de Direito do Consumidor. São Paulo: Revista dos Tribunais, n. 29, jan.-mar. 1999, p. 53, destacando a importância do plano jurisprudencial nesse contexto. 
adequada interpenetração desses direitos no seio das relações sociais. Em nenhum momento, portanto, a condição de supremacia da Constituição pode conduzir a um desprestígio do direito ordinário, situação que, ao menos em princípio, obstaculiza, de forma indiscriminada, uma aplicação direta das normas constitucionais frente a um determinado caso concreto, em detrimento das disposições legais infraconstitucionais. A sobrevalorização cega das normas constitucionais, em uma atitude de total desvalorização do direito ordinário, não traduz, em si mesma, a supremacia da Constituição; representa, isso sim, um sentimento que já foi retratado na doutrina como "fetichismo constitucional", conduta que, antes de qualquer coisa, pode levar à prática de um ativismo judicial e a uma indesejada diminuição da qualidade da produção normativa ${ }^{135}$. Nessa conectividade, todos os setores do ordenamento jurídico deveriam guardar a máxima de que "nenhum tribunal deve tomar por base para a sua decisão uma regra que nem sequer o legislador poderia ordenar ${ }^{\prime 136}$. As constituições não devem, portanto, ter a pretensão de substituir ou abafar o direito ordinário e o mesmo vale para esse em relação à judicatura ${ }^{137}$.

Nesse contexto, verifica-se o quão são acertadas as palavras de Gustavo Zagrebelsky ${ }^{138}$, quando afirma que o reconhecimento da legislação como função originária e não derivada depende que a Constituição conceba-se como um encadeamento aberto de elementos, cuja determinação histórico-concreta, dentro dos limites de elasticidade permitidos por essa realidade, seja deixado ao legislador ordinário. Pensamento contrário, para o citado jurista italiano, seria a soberba dos juristas e levaria à asfixia política por saturação política, contra a democracia, o que revela que o uso alternativo do Direito, no sentido de se derivar diretamente dos princípios constitucionais regras aplicáveis em sede jurisdicional, em alternativa às regras estabelecidas pelo legislador ordinário, representa, antes de mais nada, uma verdadeira amputação ${ }^{139}$.

É precisamente com o desiderato de sublinhar a importância do papel do direito ordinário no desenvolvimento dos direitos fundamentais que Peter

735 Es5a é a idéla defendida por REYES, Manuel Aragón. H juez Ordinario entre Legalidad y Constitucionalidad..., p. 36, (com aspas, no original), sublinhando, ainda, a importância da realizaçāo de leis de boa qualidade, como um bom caminho para que elas sejam respeitadas.

f36 Cf. ALEXY, Robert. Direito Constitucional e Direito Ordinário. Jurisdiçäo Constitucional e Jurisdição Especializada..., p. 57, referindo-se a essa expressão como a "Fómula de Scluumann".

:37 Cf. SOUZA JUNIOR, Cezar Saldanha, Direito Constitucional, Direito Ordinário, Direito fudiciário..., $p$. 12 e 16 , destacando que hipótese contrária significa a prática de um totalitarismo juridico ou de um colonialismo do direito constitucional sobre os demais ramos do Direito.

33 ZAGREBELSKY, Gustavo. El Derecho Dúctil. Ley, Derechos, Justicia..., p. 152, deixando claro que relaçäo de tensão entre a Constituiçăo e a democracia leva à comprensắo da delicada relação entre jurisdição e legislação.

${ }^{139}$ Cf. ZAGREBELSKY, Gustavo. El Derecho Dúctil. Ley, Derechos, Justicia..., p. 152. ${ }^{140}$ Cf. HÄBERLE, Peter. Die Wesensgehaltgarantie des Artikel 19 Absatz 2 Grundgesetz: zugleich ein Beitrag zum institutionellen Verständnis der Grundrechte und zur Lehre vom Gesetzesvorbehalt. 3., stark erw. Auflage. Heidelberg: C. F. Müller Juristischer Verlag GmbH, 1983, p. 184. 
Häberle ${ }^{140}$ formula a intrigante pergunta: o que seriam os direitos fundamentais sem a legislação? Para Häberle, o significado da legislação torna-se claro a partir do exato momento em que se pretenda abstrair dela, hipótese em que afirma que se faltasse aos direitos fundamentais o alicerce ou a infra-estrutura (Aufbau) da ordem jurídica de grau inferior à da Constituição, esses permaneceriam sem eficácia e ficariam "apenas no papel". Em verdade, ignorar as dificuldades não impede que elas se produzam. Se, por um lado, é indubitável que a Constituição é Direito e que todo o ordenamento jurídico deve estar subordinado à Constituição, tal condição não faz com que todos os problemas do cotidiano tenham que necessariamente ser resolvidos a partir de uma aplicaçāo direta da Constituição, como se essa fosse a única disposição normativa, à semelhança de uma caixa de mágica que contivesse todas as regras resolutórias para toda a sorte de conflitos, em uma atitude de despojamento da lei ${ }^{i^{4} \mathrm{t}}$.

Ora, esse é um claro sinal dos rumos que a ordem jurídica pode tomar, a partir do instante em que se deseje aplicar a diretamente a Constituição como remédio para todos os males. A par dessa realidade, se a Constituição contivesse em si toda a ordem jurídica, ela seria, como enfaticamente aponta Ernst Forsthoff" ${ }^{142}$, uma espécie de "ovo de Colombo jurídico, do qual tudo surge, desde o Código Penal, até a lei sobre a fabricação de termômetros", até mesmo porque, nessa ótica, teria a Constituição a pretensāo - não desejada de determinar completamente o lado normativo de cada decisão judicial especializada ${ }^{143}$. A conseqüência disso é que o tribunal encarregado de dar a última palavra em sede de jurisdiçāo constitucional acabaria por converter-se em uma superinstância revisora, contraindo para si o indesejado papel de tribunal civil supremo (oberstes Zivilgericht) ${ }^{144}$. A genial conclusão acerca da atribuição desse referido órgão é formulada por Robert Alexy ${ }^{145}$ de um modo,

$3_{40}$ CF. HÄBERLE, Peter, Die Wesensgehaltgarantie des Artikel 19 Absatz 2 Grundgesetz: zugleich ein Beitrag zum instifutionellen Verständnis der Grundrechte und zur Lehre vom Gesetzesvorbehalt. 3., stark erw. Auflage. Heidelberg: C. F. Müller luristischer Verlag GmbH, 1983, p. 184.

141 Cf. REYES, Manuel Aragón. El Juez Ordinario entre Legalidad y Constitucionalidad..., p. 37, afimando, de maneira enérgica, que a lei segue sendo, sobretudo em um estado democrático, a expressão mais ordinária do Direito.

142 FORSTHOFF, Enst. El Estado de la Sociedad Industrial..., p. 242, em traduçảo livre do autor. Confira-se a assertiva original a partir da versão espanhola da obra citada: La constitución es asi como un huevo de Colón jurídico, del que todo surge, desde el Código penal hasta Ley sobre fabricación de termómetros.

${ }^{143}$ Cf. AlEXY, Robert. Direito Constitucional e Direito Ordinário. Jurisdição Constitucional e Jurisdição Especializada..., p. 58.

sa Essa análise encontra-se no artigo de DIEDERICHSEN, Uwe. Das Bundesverfassungsgericht als oberstes Zivilgericht - ein Lehrstück der juristischen Methodenlehre. In: Archiv für die civilistische Praxis (ACP), Band 198, Heft 2-3. Tübingen: ). C. B. Mohr (Paul Siebeck), 1998, p. 257-259, oportunidade em que dirige duras críticas à possibilidade de conversão do tribunal constitucional em superinstância revisora, sobretudo na hipótese de atuaçāo do tribural constitucional ha solução de conflitos jurídico-civis.

145 ALEXY, Robert. Direito Constitucional e Direito Ordinário. Jurisdição Constitucional e Jurisdição Especializada..., p. 58, embora não concorde que o desenvolvimento constitucional verificado nos últimos cinqüenta anos seja marcado por uma sobreconstitucionalizaçăo. 
conquanto peculiar, irretocável: "seria um Moloc devorador de duas vítimas: os outros poderes e o próprio".

A aplicação direta da Constituição às relações jurídico-civis deve, portanto, limitar-se a situações excepcionais, gize-se, em casos extremos, em caráter supletivo ou subsidiário, condicionada à inexistência - se é que isso é possível, em face da existência de conceitos indeterminados e cláusulas gerais do direito civil dotadas de inegável abertura - de dispositivos legais infraconstitucionais que se mostrem capazes de resolver a controvérsia, desde, contudo, que a norma constitucional, por sua estrutura, permita essa aplicação imediata $^{146}$. Nessa hipótese, a ponderação de interesses há que assumir um relevante papel, a partir do momento em que os objetos de valoração são situações (Zustände) de regulação jurídica, de forma que valoraçōes levadas a efeito por um único critério apresentam traços de fanatismo ${ }^{147}$, o que deve ser repelido a todo o custo.

Assim, se o que define a Constituição é a sua função de dar forma ao poder, vale dizer, de criálo ${ }^{148}$, talvez seja verdade que a forma mais genuína de Direito seja a legislação ordinária, tendo em vista que se não houver lei, será muito mais difícil a existência de um autêntico Estado Democrático de Direito, ainda que igualmente admita-se que, sem Constituição, não há poder democrático ${ }^{149}$. A advertência de Manuel Aragon Reyes ${ }^{150}$ não pode ser mais direta, quando assevera que os operadores do Direito, em geral, devem ter presente que converter todo o Direito em um Direito de princípios e, pela mesma via, transformar toda a justiça em uma justiça constitucional, pode significar "promover a juridicidade... para removê-la".

Acima de tudo, o que se pode argüir com alguma margem de certeza, é que a atuação dos juízes não pode ser pautada como um poder que, livremente, aceita ou rechaça as decisões advindas do legislador ordinário, independentemente de decisões fundamentadas no Direito e em conformidade com os critérios oferecidos pelo ordenamento jurídico, sob pena de a supremacia da Constituição converter-se em "tirania dos juízes", em um cenário onde a segurança jurídica e a democracia desaparecem ${ }^{151}$. Com isso, pretende-

14́ Cf. REYES, Manuel Aragón. El Juez Ordinario entre Legalidad y Constitucionaliảad..., p. 37.

wa7 Cf. ALEXY, Robert. Theorie der Grundrechte..., p. 130-131, destacando que para que se chegue a uma valoraçăo total de uma controvérșia, quando os critérios valorativos para a soluçăo do conflito entram em colisăo, há que se estabelecer entre eles uma relaçâo que permita ponderálos, em vista de um eventual caráter contraposto.

248 Cf. LLORENTE, Francisco Rubio. La Forma del Poder. Estudios sobre la Constitución.... p. XXIV (prólogo).

149 Essa é a conclusão de REYES, Manuel Aragón. El juez Ordinario entre Legalidad y Constitucionalidad ..., p. 45-46.

150 REYES, Manuel Aragón. El fuex Ordinario entre Legalidad y Constitucionalidad..., p. 46.

15: Essa é a precisa liçăo de LLORENTE, Francisco Rubio. La Forma del Poder. Estudios sobre la Constitución..., p. 600-601 (aspas no original). 
se afirmar, na esteira de Konrad Hesse ${ }^{152}$, que o juiz não deve valer-se da sua visão de mundo, como meio para restringir a liberdade de conformação do legislador. Nesse encadeamento de idéias, o relevante debate a ser travado para a construção de um autêntico Estado. Democrático de Direito gravita, pois, na determinação da natureza da obrigação que a existência dos direitos fundamentais impõe ao legislador ordinário, bem como acerca do conteúdo desses direitos ${ }^{153}$.

\section{Considerações finais}

À guisa de encerramento, sustenta-se que a constatação do caráter supremo da Constituição não resulta, de maneira alguma, em um desprestígio do direito ordinário. Ocorre que sem o alicerce das normas infraconstitucionais, a Constituição seria como um pássaro sem asas: nunca alçaria vôo. Por isso, há que se combater, com veemência, a indistinta e ilimitada possibilidade de o Poder Judiciário examinar a compatibilidade dos meios idealizados pelo legislador para atingir determinado fim, dentre as opçōes políticas verificadas no momento da elaboração de uma lei, mediante a aplicação direta e imediata, em toda e qualquer circunstância, das normas constitucionais para a solução de casos concretos. Com total acerto procedeu Konrad Hesse ${ }^{154}$, portanto, quando escreveu que o legislador é quem, efetivamente, deve ser chamado em primeiro lugar para a tarefa de concretizar a Constituição.

Hipótese contrária significa admitir a possibilidade - e a conveniência - de os órgãos judiciais chamarem para si a realização de uma tarefa de todo ideologizante, típica dos órgãos políticos de legiferação. Decerto, essa roupagem não é desejada pelo Poder Judiciário, cuja importante missão é, diga-se de passagem, bem distinta. À vista disso, transformar toda a justiça em uma justiça constitucional significa engessar o ordenamento político-jurídico e isso, definitivamente, não é um reflexo da supremacia da Constituição, mas, talvez, de um anseio que pretenda liquidar com a democracia, dando vida ao germe do totalitarismo, ainda que com feições jurídicas.

Por conseguinte, caso se queira realmente compreender a ordem jurídica como um todo, no debate sobre a supremacia da Constituição não se pode excluir a importância que o direito ordinário possui para a manutenção do Estado Democrático de Direito. Somente ciente dessa relevância é que se pode partir para a questão fundamental que, nos termos já afirmados no presente trabalho, é a determinação da natureza da obrigação que a existência dos direitos fundamentais impõe ao legislador ordinário, bem como a determinaçāo do conteúdo desses direitos.

152 HESSE, Konrad. Elementos de Direito Constitucional da República Federal da Alemanha..., p. 257, deixando ciaro que o juiz não deve pôr a sua concepção no lugar da concepção da maioria nos corpos legisłativos, a não ser que a liberdade de decisão do legislador, fundada na ordem democrática da Constituição, deva ser mais limitada do que a Constituição o prevê.

153 Cf. LLORENTE, Francisco Rubio. La Forma del Poder, Estudios sobre la Constitución..., p. 601.

${ }_{154}$ HESSE, Konrad. Elementos de Direito Constitucional da República Federal da Alemanha..., p. 73. 


\section{Referências bibliográficas}

ALEXY, Robert. Direito Constitucional e Direito Ordinário. Jurisdição Constitucional e Jurisdiçăo Especializada. Tradução de Luís Afonso Heck. Revista dos Tribunais. São Paulo: Revista dos Tribunais, n. 809, ano 92, mar. 2003, p. 54-73.

Theorie der Grundrechte. Baden-Baden: Suhrkamp Taschenbuch Wissenschaft, 1994.

Theorie der juristischen Argumentation. Die Theorie des rationalen Diskurses als Theorie der juristischen Begründung. 3. Auflage. Frankfurt am Main: Suhrkamp Taschenbuch Wissenschaft, 1996.

ALFARO AGUILA-REAL, Jesús. Autonomia Privada y Derechos Fundamentales. In: Anuário de Derecho Civil. Madrid, tomo XLVI, fascículo 1, jan. - mar. 1993, p. 57-122.

BARROS, Suzana de Toledo. O Princípio da Proporcionalidade e o Controle de Constitucionalidade das Leis Restritivas de Direitos Fundamentais. 2.ed. Brasília: Brasília Jurídica, 2000.

BUENO, José Antonio Pimenta. Direito Publico Brazileiro e Analyse da Constituição do Imperio. Rio de Janeiro: J Villeneuve e Cia, 1857.

CACHAPUZ, Maria Cláudia. Intimidade e Vida Privada no Novo Código Civil Brasileiro. Uma leitura orientada no discurso jurídico. Porto Alegre: Sergio Antonio Fabris Editor, 2006.

CANARIS, Claus-Wilhelm. Grundrechte und Privatrecht. Eine Zwischenbilanz. Berlin New York: Walter de Gruyter, 1999.

COMMELA, Víctor Ferreres. Las Consecuencias de Centralizar el Control de Constitucionalidad de la Ley en un Tribunal Especial. Algunas Reflexiones acerca def Activismo Judicial Disponivel em: < http://islandia.law.yale.edu/selal eprog04.htm> Acesso em: 29 set. 2005, p. 1-33.

DIEDERICHSEN, Uwe. Das Bundesverfassungsgericht als oberstes Zivilgericht -- ein Lehrstück der juristischen Methodentehre. In: Archiv für die civilistische Praxis (ACP), Band 198, Heft 2-3. Tübingen: J. C. B. Mohr (Paul Siebeck), 1998, p. 171-260.

FORSTHOFF, Ernst. El Estado de la Sociedad Industrial. Traducido por Luis López Guerra e Jaime Nicolás Muñiz. Madrid: Instituto de Estudios Politicos, 1975. Tradução de: Der Staat der Industriegesellschaft.

GADAMER, Hans-Georg. Warheit und Methode. Grundzüge einer philosophischen Hermeneutik. 6. durchgesehende Auflage. Tübingen: ). C. B. Mohr (Paul Siebeck), 1990, Band I.

GRIMM, Dieter. Die Zukunft der Verfassung. Frankfurt am Main: Suhrkamp, 1991.

HÄBERLE, Peter. Die Menschenwürde als Grundlage der staatlichen Gemeinschaft. In: ISENSEE, Josef; KIRCHHOF, Paul. (Hrsg.). Handbuch des Staatsrechts der Bundesrepublik Deutschland. 3. Auflage. Heidelberg: C. F. Müller Juristischer Verlag $\mathrm{GmbH}$, Band II, 2003, p. 317-367. 
Die Wesensgehaltgarantie des Artikel 19 Absatz 2 Grundgesetz: zugleich ein Beitrag zum institutionellen Verständnis der Grundrechte und zur Lehre vom Gesetzesvorbehalt. 3., stark erw. Auflage. Heidelberg: C. F. Müler Juristischer Verlag GmbH, 1983.

HECK, Luís Afonso. Direitos Fundamentais e sua Influência no Direito Civil. Revista de Direito do Consumidor. São Paulo: Revista dos Tribunais, n. 29, jan.-mar. 1999, p. 40-54.

O Controle Normativo no Direito Constitucional Brasileiro. Revista dos Tribunais. São Paulo: Revista dos Tribunais, n. 800, ano 91, jun. 2002, p. 57-64.

O Tribunal Constitucional Federal e o Desenvolvimento dos Prinć́pios Constitucionais. Contributo para uma compreensão da jurisdição constitucional federal alemã. Porto Alegre: Sergio Antonio Fabris, 1995.

In: CACHAPUZ, Maria Cláudia. Intimidade e Vida Privada no Novo Código Civil Brasileiro. Uma leitura orientada no Discurso Jurídico. Porto Alegre: Sergio Antonio Fabris Editor, 2006 (prefácio), p. 11-30.

HESSE, Konrad. Elementos de Direito Constitucional da República Federal da Alemanha. Traduzido por Luis Afonso Heck. Porto Alegre: Sergio Antonio Fabris, 1998. Tradução de: Grundzüge des Verfassungsrechts der Bundesrepublik Deutschland "20., neubearbeitete Auflage.

Verfassungsrecht und Privatrecht. Heidelberg: C. F. Muller Juristischer Verlag, 1988.

HORTA, Raul Machado. Poder legislativo monopólio da lei no mundo contemporâneo. Revista de Informação Legislativa. Brasília: Senado Federal, ano 31, n. 123, jul.set. 1994, p. 149-158.

JELLINEK, Georg. System der Subjektiven Öffentlichen Rechte. 2. Auflage. Tübingen: I. C. B. Mohr (Paul Siebeck), 1919

Teoria General del Estado. Traduzido por Fernando de los Rios. Buenos Aires: Albatros, 1971. Tradução de: Allgemeine Staatslehre.

KELSEN, Hans. Reine Rechtslehre. 2. erw. Auflage. Wien: Franz Deuticke, 1983.

Wer soll der Hüter der Verfassung sein? In: Die Justiz. Monatsschrift für Erneuerung des Deutschen Rechtswesens, Band VI, Doppelheft 11/12. Berlin-Grunewald, 19301931 , p. 576-628.

Wesen und Entwicklung der Staatsgerichtsbarkeit. In: Veröffentlichungen der Vereinigung der Deutschen Staatsrechtslehrer (VVDStRL), Heft 5. Berlin und Leipzig: Walter de Grunyter, 1929, p. 30-84.

LLORENTE, Francisco Rubio. Divide et Obtempera? Una reflexión desde España sobre el modelo europeo de convergencia de jurisdicciones en la protección de los derechos. Revista Española de Derecho Constitucional. Madrid: Centro de Estudios Políticos y Constitucionales, n. 67, ano 23, jan-abr de 2003, p. 49-67. 
La Forma del Poder. Estudios sobre la Constitución. 2.ed. Centro de Estudios Constitucionales: Madrid, 1997.

LOEWENSTEIN, Karl. Teoria de la Constitución. Traduzido por Alfredo Gallego Anabitarte. 2.ed. aum. Barcelona: Ariel, 1976. Traduçäo de: Verfassungslehre.

MARQUES, Claudia Lima. Superação das Antinomias pelo Diálogo das Fontes: o modelo brasileiro de coexistência entre o Código de Defesa do Consumidor e o Código Civil de 2002. Revista de Direito do Consumidor. Säo Paulo: Revista dos Tribunais, n. 51, jul-set de 2004, p. 34-67.

MARTINNEZ-PUJALTE, Antonio Luis. La Garantia del Contenido Esencial de los Derechos Fundamentales. Madrid: Centro de Estudios Constitucionales, 1997.

MARTINS-COSTA, Judith. O Novo Código Civil Brasileiro: em Busca da "Ética da Situação". In: MARTINS-COSTA, Judith; BRANCO, Gerson Luiz Carlos. Diretrizes Teóricas do Novo Código Civil Brasileiro. São Paulo: Saraiva, 2002, p. 87-168.

MAURER, Hartmut. Direito Administrativo Geral. Tradução de Lús Afonso Heck. Barueri: Manole, 2006. Tradução de: Allgemeines Verwaltungsrecht - 14 Auflage.

MIRANDA, Jorge. Manual de Direito Constitucional. 3.ed. Coimbra: Coimbra Editora, 1996, Tomoll.

PIEROTH, Bodo; SCHLINK, Bernhard. Grundrechte Staatsrecht II. 16., neubearbeitete Auflage. Heidelberg: C.F. Müller Verlag, 2000.

RAISER, Ludwig. O Futuro do Direito Privado. Traduzido por Lucinda Maria Ragugnetti. Revista da Procuradoria Geral do Estado do Rio Grande do Sul. Porto Alegfe: PGE, ano 9, n. 25, 1979. Tradução de: Die Zukunft des Privatrechts, p. 11-30.

REYES, Manuel Aragón. El Juez Ordinario entre Legalidad y Constitucionalidad. Bogotá: Instituto de Estudios Constitucionales Carlos Restrepo Piedrahita, 1997.

SARLET, Ingo Wolfgang. A Eficácia dos Direitos Fundamentais. 2.ed. rev. e aum. Porto Alegre: Livraria do Advogado, 2001.

SCHNEIDER, Hans Peter. Democracia y Constitucion. Madrid: Centro de Estudios Constitucionales, 1991.

SILVA, Luis Renato Ferreira da. A Função Social do Contrato no Novo Código Civil e sua Conexão com a Solidariedade Social. In: Ingo Wolfgang Sarlet (org.). O Novo Código Civil e a Constituição. Porto Alegre: Livraria do Advogado, 2003, p. 127150.

SILVEIRA, José Néri da. A Reforma Constitucional e o Controle de sua Constitucionalidade. Revista da Ajuris. Porto Alegre: Associação dos Juízes do Rio Grande do Sul, n. 64, jutho de 1995, p. 201-221.

SOUZA JUNIOR, Cezar Saldanha. A Supremacia do Direito no Estado Democrático e seus Modelos Básicos. Porto Alegre: [s.ed.], 2002. 
Direito Constitucional, Direito Ordinário, Direito Judiciário. Cadernos do Programa de Pós-Graduação em Direito da Universidade Federal do Rio Grande do Sul, março de 2005, p. 7-18.

(Informação oral). Aulas de Teoria de Direito Público do Curso de Pós-graduação em Direito da Universidade Federal do Rio Grande do Sul, 1. ${ }^{\circ}$ semestre de 2005.

STERN, Klaus. Das Staatsrecht der Bundesrepublik Deutschland. 2. neubearbeitete Auflage. München: C.H. Beck'sche Verlagsbuchhandlung, 1984, Band I. München: C.H. Beck'sche Verlagsbuchhandlung, 1988, Band III/1.

TRIBE, Laurence H.; DORF, Michael C. On Reading the Constitution. Cambridge: Harvard University Press, 1991.

ZAGREBELSKY, Gustavo. El Derecho Dúctil. Ley, Derechos, Justicia. Traduzido por Marina Gascón. 3.ed. Madrid: Editorial Trotta, 1999. Tradução de: Il Diritto Mitte. Legge, Diritti, Giustizia.

La Ley, el Derecho y la Constitución. Revista de Española de Derecho Constitucional. Madrid: Centro de Estudios Políticos y Constitucionales, n. 72, ano 24 , set-dez de 2004, p. 11-24.

ZIPPELIUS, Reinhold. Teoria Geral do Estado. Traduzido por Karin Praefke-Aires Coutinho. Lisboa: Fundação Galouste Gulbenkian, 1997. Tradução de: Allgemeine Staatslehre. 